OPEN ACCESS

Edited by:

Arnaud Zaldumbide, Leiden University Medical Center,

Netherlands

Reviewed by:

Feyza Engin,

University of Wisconsin-Madison, United States

Rocky L. Baker,

University of Colorado Denver, United States

${ }^{*}$ Correspondence: Lut Overbergh lutgart.overbergh@kuleuven.be

These authors have contributed equally to this work and share first authorship

Specialty section: This article was submitted to Autoimmune and Autoinflammatory Disorders, a section of the journal

Frontiers in Immunology

Received: 10 March 2021 Accepted: 11 May 2021 Published: 01 June 2021

Citation:

Yang M-L, Sodré FMC, Mamula MJ and Overbergh $L$ (2021) Citrullination and PAD Enzyme Biology in Type 1 Diabetes - Regulators of Inflammation, Autoimmunity, and Pathology.

Front. Immunol. 12:678953. doi: 10.3389/fimmu.2021.678953

\section{Citrullination and PAD Enzyme Biology in Type 1 Diabetes - Regulators of Inflammation, Autoimmunity, and Pathology}

\author{
Mei-Ling Yang ${ }^{1 \dagger}$, Fernanda M. C. Sodré ${ }^{2 \dagger}$, Mark J. Mamula ${ }^{1}$ and Lut Overbergh ${ }^{2 *}$ \\ 1 Section of Rheumatology, Allergy and Clinical Immunology, Department of Internal Medicine, Yale University, New Haven, \\ CT, United States, ${ }^{2}$ Department of Chronic Diseases, Metabolism and Ageing, Laboratory of Clinical and Experimental \\ Endocrinology (CEE), KU Leuven, Leuven, Belgium
}

The generation of post-translational modifications (PTMs) in human proteins is a physiological process leading to structural and immunologic variety in proteins, with potentially altered biological functions. PTMs often arise through normal responses to cellular stress, including general oxidative changes in the tissue microenvironment and intracellular stress to the endoplasmic reticulum or immune-mediated inflammatory stresses. Many studies have now illustrated the presence of 'neoepitopes' consisting of PTM self-proteins that induce robust autoimmune responses. These pathways of inflammatory neoepitope generation are commonly observed in many autoimmune diseases including systemic lupus erythematosus, rheumatoid arthritis, multiple sclerosis, and type 1 diabetes (T1D), among others. This review will focus on one specific PTM to self-proteins known as citrullination. Citrullination is mediated by calcium-dependent peptidylarginine deiminase (PAD) enzymes, which catalyze deimination, the conversion of arginine into the non-classical amino acid citrulline. PADs and citrullinated peptides have been associated with different autoimmune diseases, notably with a prominent role in the diagnosis and pathology of rheumatoid arthritis. More recently, an important role for PADs and citrullinated self-proteins has emerged in T1D. In this review we will provide a comprehensive overview on the pathogenic role for PADs and citrullination in inflammation and autoimmunity, with specific focus on evidence for their role in T1D. The general role of PADs in epigenetic and transcriptional processes, as well as their crucial role in histone citrullination, neutrophil biology and neutrophil extracellular trap (NET) formation will be discussed. The latter is important in view of increasing evidence for a role of neutrophils and NETosis in the pathogenesis of T1D. Further, we will discuss the underlying processes leading to citrullination, the genetic susceptibility factors for increased recognition of citrullinated epitopes by T1D HLA-susceptibility types and 
provide an overview of reported autoreactive responses against citrullinated epitopes, both of $T$ cells and autoantibodies in T1D patients. Finally, we will discuss recent observations obtained in NOD mice, pointing to prevention of diabetes development through PAD inhibition, and the potential role of PAD inhibitors as novel therapeutic strategy in autoimmunity and in T1D in particular.

Keywords: type 1 diabetes, neoepitopes, post-translational modification, citrullination, peptidylarginine deiminase

\section{ORIGIN AND IMPLICATIONS OF POST- TRANSLATIONAL MODIFICATIONS IN AUTOIMMUNITY}

At a simplistic level, the success of immunity relies on distinguishing 'self' from 'non-self, originating primarily by purging the autoreactive repertoire both in central lymphoid organs, the thymus and bone marrow, as well as by peripheral tolerance mechanisms. Classical mechanisms of immune tolerance rely on the processing and presentation of selfpeptides by antigen presenting cells (APCs), resulting in deletion or anergy of the autoimmune repertoire. However, it is clear that many self-proteins, or post-translational modifications (PTMs) to self-proteins, are not expressed in primary lymphoid organs. For example, PTMs specific to peripheral tissues may not be expressed in the thymus and thus these PTMs never tolerize or delete the emerging thymocytes. While we know that proteins are fundamentally assembled from 20 amino acid structures, the addition of PTMs pushes that group above 140 structurally unique amino acids (1). These observations have altered the concepts and the breadth of immune tolerance to self-proteins, particularly in the perspective of autoimmune syndromes. Many factors influence the rate at which PTMs arise in self-proteins, including the amino acid sequence, flanking amino acid motifs, and variables such as the tissue microenvironments. PTMs also alter specific peptides that arise by antigen processing and, subsequently, the specificity of ongoing B- and T-lymphocyte immunity (2-4).

Some PTMs arise by enzymatic processes, as with citrullination reviewed herein, or with N-linked glycosylation or phosphorylation, critical to biological functions of many host proteins. In contrast, some modifications arise spontaneously, under physiologic $\mathrm{pH}$ and temperature, such as the formation of isoaspartyl modifications [reviewed by (5)]. Also, some modifications can be processed either enzymatically or spontaneously, such as deamidation (6). As illustrated herein, PTMs may trigger aberrant autoimmunity as well as alter the biological functions of self-proteins in selected tissues, including transcriptional and translational events. The text that follows will review the conditions that elicit citrulline PTMs, including their role in biological and immunological processes, with specific focus on their implications in type 1 diabetes (T1D).

Citrullination, also known as deimination, is a PTM in which an arginine residue is converted into a citrulline (Figure 1). This modification, which was first described in 1939 (7), leads to a loss of one positive charge and a reduction in mass of $0.984 \mathrm{Da}$ per modified arginine. This type of modification can alter intra- and inter-molecular interactions of the protein (8), having an impact on its structure, function and its interaction with other proteins (9). Citrullination is catalyzed by peptidylarginine deiminase (PAD) enzymes in a $\mathrm{Ca}^{2+}$-dependent manner (10), which is thought to be an irreversible process (11).

A role for citrullinated self-proteins has been associated with several autoimmune diseases, such as T1D, rheumatoid arthritis (RA), systemic lupus erythematosus (SLE), multiple sclerosis (MS), psoriasis, Sjögren's syndrome (SS), antiphospholipid syndrome (ALS) and inflammatory bowel disease (IBD) (Table 1). Among these different autoimmune diseases, citrullination as an autoimmune biomarker in RA has been most extensively described. RA is a chronic autoimmune disease characterized by inflammation of the synovial joints. Proteomic analysis of the cellular and soluble components of RA synovium identified the full RA citrullinome, with more than 100 citrullinated proteins, amongst which vimentin, enolase, fibrinogen and fibronectin (46). Some of these were shown to induce autoantibodies and/or autoreactive T-cell responses in RA (11, 22, 29, 30). The presence of anti-citrullinated protein antibodies (ACPAs) in the serum of RA patients is one of the most specific diagnostic marker for the disease (47). ACPAs can be detected years before clinical symptoms appear (48). Apart from being a prognostic biomarker for disease development, some ACPAs have been described as useful in predicting the severity of joint destruction during the first five years after RA onset (49). ACPAs can also be detected in a small percentage of patients with SS (3 to 9.9\%), and the presence of such

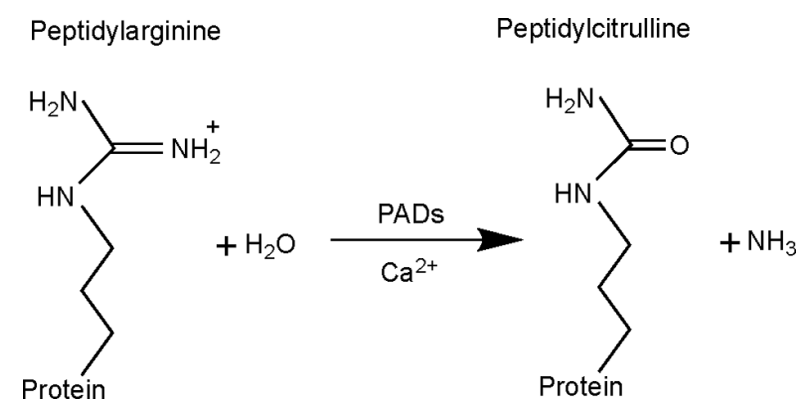

FIGURE 1 | Citrullination reaction catalyzed by peptidylarginine deiminase (PAD) enzymes. With the conversion of arginine into citrulline, the primary ketamine group of arginine $(=\mathrm{NH})$ is replaced by a ketone group $(=0)$, with production of ammonia as a side-product. This results in a mass difference of $0.984 \mathrm{Da}$ and loss of one positive charge. Citrullination is catalyzed by PAD enzymes, requiring $\mathrm{Ca}_{2}^{+}$as cofactor. 
TABLE 1 | Citrullination in autoimmune diseases.

\begin{tabular}{|c|c|c|}
\hline Diseases & Target proteins & References \\
\hline & $\mid A-2$ & $(13)$ \\
\hline & IGRP & (13) \\
\hline & IAPP & $(17,18)$ \\
\hline \multirow[t]{4}{*}{ Rheumatoid arthritis (RA) } & fibrinogen & $(19-21)$ \\
\hline & vimentin & $(22-24)$ \\
\hline & $\alpha$-enolase & (29) \\
\hline & GRP78 & (30) \\
\hline \multirow[t]{2}{*}{ Systemic lupus erythematosus (SLE) } & LL37 & (31) \\
\hline & histone $\mathrm{H} 1$ and $\mathrm{H} 3$ & $(26,32)$ \\
\hline \multirow[t]{2}{*}{ Multiple sclerosis (MS) } & MBP & $(33-36)$ \\
\hline & GFAP & (36) \\
\hline \multirow[t]{2}{*}{ Sjögren's syndrome (SS) } & histone $\mathrm{H} 1$ & (41) \\
\hline & $\alpha$-enolase & (42) \\
\hline Antiphospholipid syndrome (ALS) & vimentin & (43) \\
\hline Inflammatory bowel disease (IBD) & vimentin & $(44,45)$ \\
\hline
\end{tabular}

GAD65, glutamic acid decarboxylase 65; IA-2, islet antigen-2; GRP78, glucose-regulated protein 78; IGRP, islet-specific glucose-6-phosphatase catalytic subunit-related protein; IAPP, islet amyloid polypeptide; MBP, myelin basic protein; GFAP, glial fibrillary acidic protein.

autoantibodies indicates a risk of developing RA (50). As listed in Table 1, emerging citrullinated target proteins are proposed as autoimmune disease specific biomarkers. Interestingly, the serological level of citrullinated vimentin in patients with ulcerative colitis (UC) was decreased compared to patients with another important IBD, Crohn's disease (CD), and non-IBD control subjects. Therefore, citrullinated vimentin has also been suggested as differentiating marker between $\mathrm{CD}$ and $\mathrm{UC}$ to improve the diagnostic accuracy in IBD (44).

\section{PEPTIDYLARGININE DEIMINASES: TYPES AND MECHANISM OF ACTION}

Peptidylarginine deiminases are a group of 5 enzymes encoded by genes localized on chromosome 1p36.1 in human and chromosome $4 \mathrm{E} 1$ in mice, located in a cluster of $350 \mathrm{~kb}$ and $240 \mathrm{~kb}$, respectively (51). They were first described in 1977 as the enzymes mediating the conversion of arginine into the nonclassical amino acid citrulline in proteins, from studies performed in mammalian hair follicles (52). The enzyme responsible for this reaction was for the first time partially purified by Fujisaki and Sugawara in 1981 and named peptidylarginine deiminase (PAD) (53). Since then, five different PAD isozymes have been described in mammals, designated as PAD1 to PAD4 and PAD6, which display 50$70 \%$ sequence identity (54). PADs replace the primary ketamine group of arginine $(=\mathrm{NH})$ by a ketone group $(=\mathrm{O})$ and yield ammonia as a side-product (Figure 1), leading to the loss of one positive charge of the target protein. This can lead to changes in the function and fate of the citrullinated target protein.
Although the PAD enzymes are widely expressed throughout the body, and have been implicated in a variety of physiological processes, each isozyme has specific tissue distribution, functions, and substrates under physiological conditions (8) (Figure 2 and Table 2). As such, PAD1 is predominantly expressed in skin epidermis, uterus and hair follicles, targeting keratin and filaggrin (86). PAD2 is the ubiquitous member of the family, being expressed in multiple tissues such as brain, skeletal muscle, spleen, uterus, secretory glands and leukocytes $(60,65$, 71). Importantly, PAD2 and PAD4 are the only PAD isozymes expressed in immune cells. Amongst other targets, PAD2 citrullinates myelin basic protein (MBP) in brain, vimentin in skeletal muscle and macrophages, actin in neutrophils and histones in various cell types (71). PAD3 is found in hair follicles and epidermis, and citrullinates filaggrin, trichohyalin, apoptosis-inducing factor (AIF) and vimentin (86). PAD4 is expressed in leukocytes, mainly granulocytes (like neutrophils and eosinophils), and monocytes and macrophages $(63,73)$. It is the only PAD isotype with a nuclear localization signal sequence, which is located at its $\mathrm{N}$-terminus. PAD4 targets several nuclear proteins, such as histones, nucleophosmin and nuclear lamin $\mathrm{C}$ (71). With its high expression in neutrophils, PAD4 plays an important role in the generation of neutrophil extracellular traps (NETs) and thereby in the first line of defense against bacterial pathogenic invaders (see in more detail below). PAD6 is mainly expressed in eggs, embryo and ovary. It is the only PAD isozyme for which until today no protein substrates have been identified (86) and, in vitro, no catalytic activity can be measured (89). Also, no known association with autoimmunity or other diseases has been reported for PAD6.

Although all 5 PAD enzymes target arginine residues in proteins, they do have different substrate specificities. The basis 


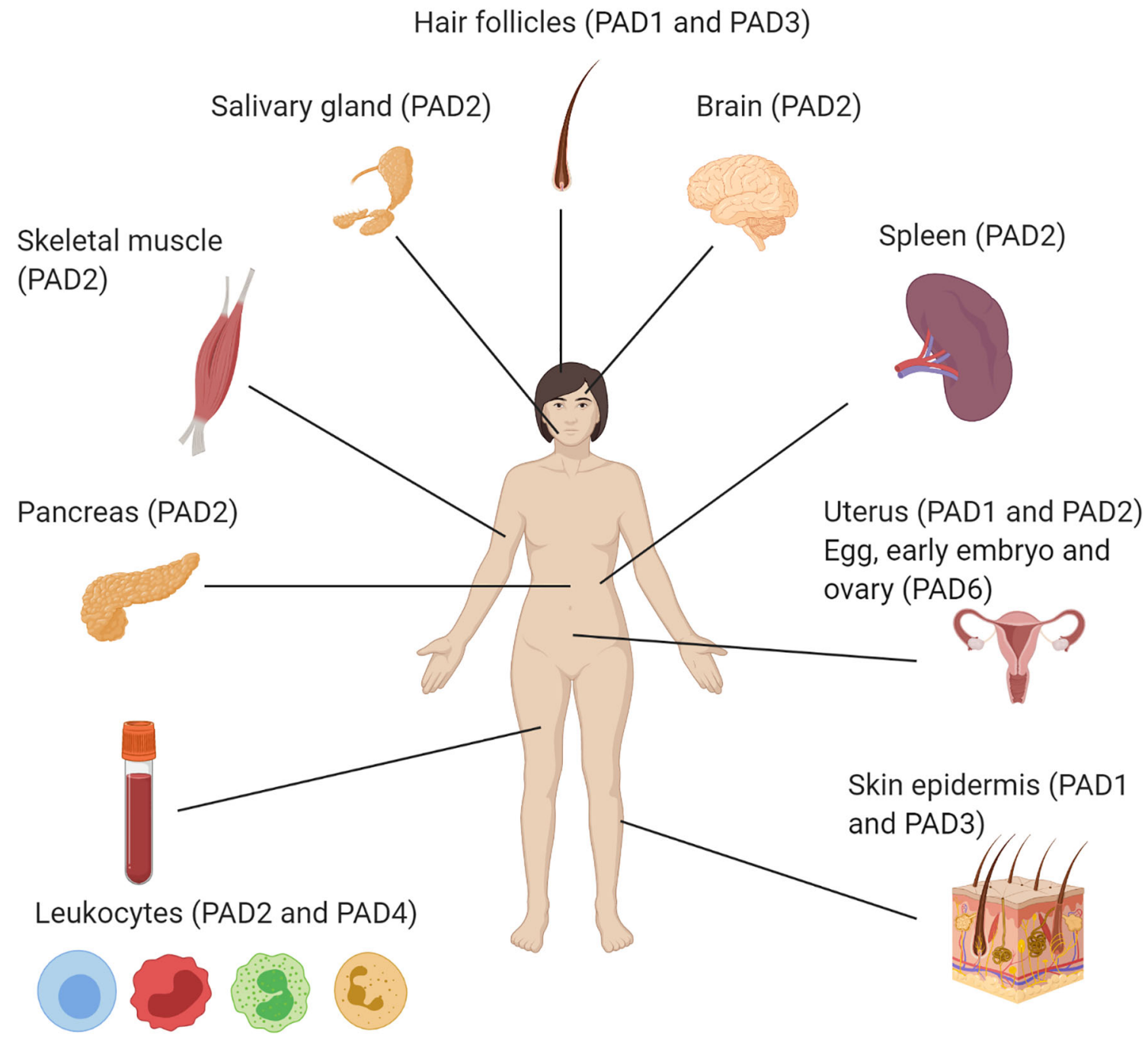

FIGURE 2 | Illustration of the organ-specific protein expression of peptidylarginine deiminase isozymes in humans.

TABLE 2 | PAD isozymes tissue distribution, target substrates, physiological functions and disease association.

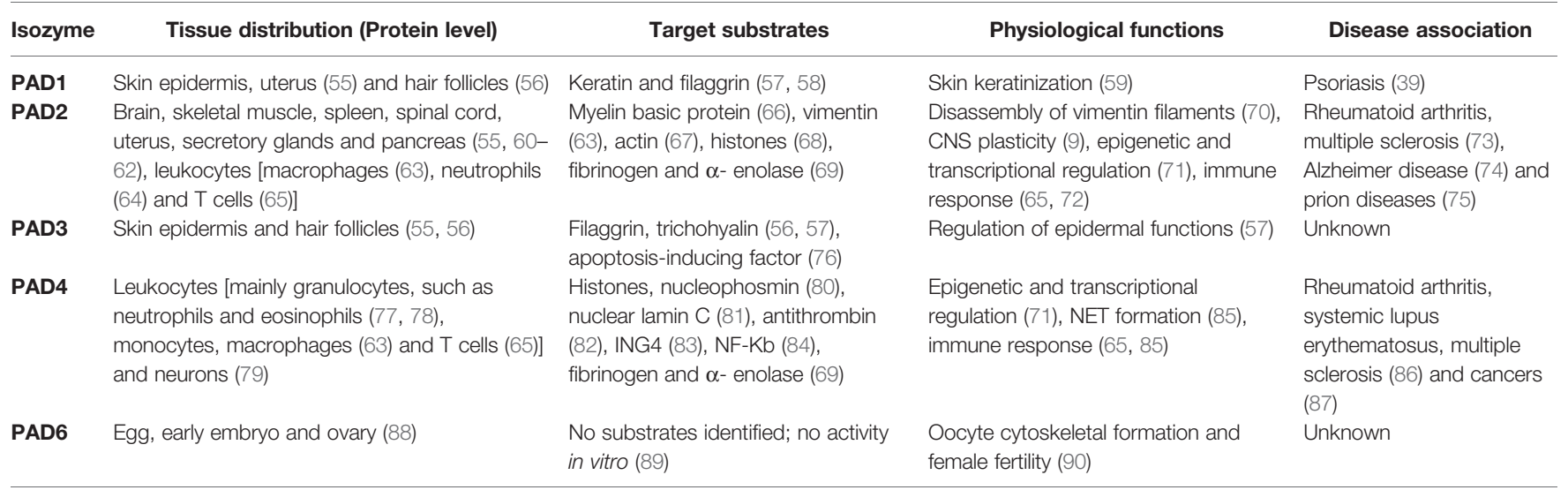

ING4, inhibitor of growth 4; CNS, central nervous system; NET, neutrophil extracellular trap. 
for this difference is not fully understood, but cannot solely be explained by their difference in tissue distribution or subcellular location (54). Additional influencing factors include the enzyme kinetics, the conformation of the secondary structure of the target protein and the flanking amino acid composition surrounding the arginine residues, as revealed from in vitro studies with recombinant $\mathrm{PAD}$ enzymes. In regard to the latter, it was shown for instance that a glutamic acid accompanying the arginine residue decreases the chance of being citrullinated, whereas a flanking aspartic acid residue increases the citrullination level (91). In this regard, PAD4 was found to have a higher substrate specificity as compared to PAD2 $(92,93)$.

The most important regulator of $\mathrm{PAD}$ activity is calcium, with micro to millimolar calcium concentrations needed for their full activation $(53,54,94)$. However, under physiological conditions, with intracellular cytosolic calcium concentrations usually around 100-fold lower, a basal PAD activity can also be measured, in line with the occurrence of low levels of citrullination and their role during normal physiological processes. This raises questions as to how exactly calcium is mediating the activity of PADs. One thought is that calcium may alter the confirmation of PADs. Under low calcium conditions, PADs may be present in a conformation that selects only high efficiency substrates, thus allowing citrullinations to happen, but limiting aberrant citrullination events (11). In the presence of high calcium, all calcium binding sites of the PAD enzyme are occupied, promoting extensive rearrangement and dimerization of the enzyme, leading to its full activation, as shown for PAD4 $(95,96)$. Alternatively or additionally, other factors are known to regulate PAD enzymes (9), which could act as cofactors modulating their calcium sensitivity and specificity (11). Considering the importance of calcium in PAD activation, pathways that alter intra- or extracellular calcium levels, such as endoplasmic reticulum (ER) and inflammatory stress, are important in many of the autoimmune diseases in which citrullination is implicated (see in more detail below) and underscore the important link between citrullination and stress pathways. Indeed, changes in calcium fluxes may lead to activation of PAD activity in stressed or dying cells. Moreover, the externalization and activation of intracellular PAD enzymes into the extracellular space may occur in the surroundings of dying cells. This may explain the citrullination of extracellular proteins, as observed for instance during NET formation (NETosis) (see in detail below) or the citrullination of beta-cell proteins as observed in T1D (15). Similar observations in RA show that PADs are highly activated by $\mathrm{Ca}^{2+}$ ion deposition in the inflamed joints, particularly during apoptotic cell death (97, 98 ), leading to elevated levels of citrullinated proteins and peptides.

\section{PROTEIN CITRULLINATION DETECTION}

The first antibody-based methodology for citrullinated protein detection was described in 1992 by Senshu et al. (99).
The antibody does not recognize citrulline residues directly but instead binds a chemically modified form, diacetyl monoxime and antipyrine derivatized-citrulline, now available in commercialized kit form. The approach utilizes protein samples separated by SDS-PAGE, transferred to a microporous membrane. The membrane bound citrulline-containing proteins are modified in the presence of 2,3-butanedione monoxime and antipyrine in acid condition. In a similar concept known as the "Senshu" method, Moelants et al. developed a sandwich ELISA format to detect citrullinated proteins utilizing antibody recognizing 2,3-butanedione-modified citrulline (100). Another citrulline-specific labeling chemical probe, rhodamine-tagged phenylglyoxal derivative (Rh-PG), was developed for detection of citrullinated proteins in both purified protein sample and complex mixtures including serum $(101,102)$.

There are now commercially available anti-peptidyl citrulline antibodies for detection of citrullinated proteins including mouse monoclonal IgM antibody, clone F95, from Millipore (MABN328), and rabbit polyclonal antibody from Upstate (07377) or Abcam (ab10092 and ab6464). Clone F95 antibody is extensively used in tissue staining, immunoblot and ELISA (25, $103,104)$. The specificity and sensitivity of the above commercial anti-peptidyl citrulline antibodies for differentiating arginine citrullination and lysine carbamylation were recently discussed (105). Of note, carbamylation is a non-enzymatic PTM converting lysine to homocitrulline, which shares similar structural features with citrulline. For specific citrullinated target proteins, a variety of commercially available or in-house produced antibodies are available, such as those specific to citrullinated-histones, hypoxia-inducible factor 1- $\alpha$, vimentin, fibrinogen, MBP and GRP78.

Upon citrullination, $0.984 \mathrm{Da}$ mass increase from the parent peptide can be identified by mass spectrometry. As this is exactly the same increase in mass as for deamidated peptides, caution is needed when analyzing liquid chromatography-tandem mass spectrometry (LC-MS/MS) data, not to misinterpret a citrullinated peptide from a deamidated peptide on a closeby $\mathrm{N}$ - or $\mathrm{Q}$ residue. On top of that, $\mathrm{C}^{13}$ isotopes, with an increase in mass of $1 \mathrm{Da}$ compared to $\mathrm{C}^{13}$ parent ions, can also be wrongfully identified as deamidated or citrullinated residues, even with the use of very accurate mass spectrometry instrumentation and strict settings. A recent study by Callebaut et al. (6) outlines critical parameters to detect deamidated residues by LC-MS/MS, through minimizing artificial in vitro occurring deamidations and manual inspection of spectra. This same method can also be applied for critical evaluation of citrullinated peptides from LCMS/MS analysis. Another issue to be considered is that the loss of one positive charge of the arginine residue due to citrullination will affect protease cleavage efficiency for proteases which cleave after arginine, such as trypsin. This will result in mis-cleavages by trypsin, in case the arginine is citrullinated (106). Of particular interest is the dual search delta score method developed by Qian laboratory which integrates several critical parameters for identifying citrullinated and deamidated peptides in an automated way, thereby decreasing false discovery rates (FDR) (107). A different method used for facilitating LC-MS/MS-based 
detection of citrullinated proteins is chemical derivatization of citrulline residues by 2,3-butanedione alone or combined with antipyrine, resulting in a mass increase of 50 or $238 \mathrm{Da}$, respectively $(108,109)$. Chemical derivatization of citrulline residues can also be used for enrichment of citrullinated proteins, through the use of biotin-conjugated phenylglyoxal (BPG), prior to LC-MS/MS analysis (101, 102). This method, however, requires large amounts of starting material. In addition, a BPG-based ELISA platform recently developed will validate the mass spectrometry proteomic data for citrullination detection (110).

\section{INFLAMMATORY PATHWAYS INCREASE CITRULLINATION AND OTHER PTMS}

Simply put, autoimmunity is initiated when cellular and soluble components of the immune system interact to trigger the recognition and robust response to self-proteins leading to tissue pathology. Additionally, a large number of heritable genetic risk traits have been defined by genome wide association studies (GWAS) in many autoimmune syndromes. However, autoimmune syndromes and T1D, in particular, are not entirely explained by a defined collection of heritable genetic traits. Indeed, poorly defined environmental influences and epigenetic factors, which may or may not be inherited, also influence the early onset and progression of T1D (111). Of importance, the amplification of PTMs in T1D autoimmunity is clearly linked to oxidative tissue environments. Reactive oxygen species (ROS), including superoxide anion $\left(\mathrm{O}_{2}{ }^{-}\right)$, hydrogen radicals $\left(\mathrm{OH}\right.$.), and hydrogen peroxide $\left(\mathrm{H}_{2} \mathrm{O}_{2}\right)$ are a product of a dynamic balance of endogenous anti-oxidant cellular compounds that control their tissue concentrations and biological effects. These anti-oxidants include superoxide dismutase (SOD), glutathione peroxidase, catalase, peroxiredoxins, as well as other small molecule anti-oxidants, including vitamins $\mathrm{E}$ and $\mathrm{C}$. There are potentially a number of sources of specific ROS in tissue autoimmunity, including the infiltration of activated phagocytic cells (neutrophils, macrophages and dendritic cells) which have been demonstrated to be important in the progression and tissue pathology of T1D as well as many other autoimmune syndromes.

Oxidative stress can amplify the modification of certain proteins, or protein motifs, or, alternatively, alter metabolic pathways. As described in detail below, there are secondary effects of ROS on apoptosis, NETosis, and cellular metabolic pathways, affecting the progression of autoimmune responses and tissue pathology. ROS affected proteins may be changed in solubility, reduce the ability of proteins to be cleared, or increase immunogenicity. As detailed below, oxidation and subsequent citrullination can also provoke changes at both the level of DNA transcription and translation.

Citrullination of histone $\mathrm{H} 3$ by PAD4 in granulocytes, leading to formation of NETosis, is a process which is promoted by intracellular $\mathrm{ROS}(85,112)$. Also, exogenous $\mathrm{H}_{2} \mathrm{O}_{2}$ was shown to induce citrullination and NETosis in mouse neutrophils (85).
Depending on the stimulus used, the level and time course of ROS production was shown to be important for subsequent $\mathrm{H} 3$ citrullination and NET formation (113). However, seemingly contradictory to this notion, in vitro studies showed a direct inhibitory effect of PAD2 and PAD4 activity in the presence of $\mathrm{H}_{2} \mathrm{O}_{2}$ concentrations above $40 \mu \mathrm{M}$. In addition, PMA-stimulated leukocytes could effectively citrullinate recombinant fibrinogen, although this process was markedly enhanced when ROS formation was inhibited by the NADPH oxidase inhibitor diphenyleneiodonium (DPI) (114). These findings suggest that although ROS is important intracellularly for mediating citrullination of histones, supraphysiological levels of ROS may inhibit citrullination extracellularly. Discrepancies in different studies on the exact role of ROS in PAD activation and citrullination may need further examination to resolve the impact of intra- vs. extracellular ROS concentrations.

Another important factor mediating PAD activity is the local redox balance, with a reducing environment needed for efficient $\mathrm{PAD}$ activation. As such, in vitro studies, making use of the nonphysiological reducing agent dithiothreitol (DTT), have shown that PADs can be activated under reducing conditions. Also more physiological reducing agents, like thioredoxin (115) and reduced glutathione (GSH) (116) can activate PAD enzymes. Kinetic characterization of PAD4 using thioredoxin as reducing agent produced results equivalent to those obtained with DTT (115).

Clearly, ER stress is a key factor in the amplification of PTMs in T1D. The insulin producing beta-cell, i.e. the immune targeted cell in T1D, is particularly sensitive to ER stress, because of its highly developed ER needed to cope with the high demands for protein translation and folding (117-119), in response to acute changes in blood glucose levels. As such, beta-cells can increase the translation of preproinsulin up to 25 -fold (120), reaching almost 1 million molecules of preproinsulin per minute (121), when blood glucose levels are high. In order to restore the equilibrium between the cellular demand for protein synthesis and the ER folding capacity, cells under ER stress activate the unfolded protein response (UPR) (122). The UPR is activated by three transmembrane protein sensors, activating transcription factor 6 (ATF6), protein kinase RNA-like ER kinase (PERK) and inositol-requiring kinase 1 (IRE1). Under physiological conditions, these three sensors are kept in an inactive state through binding to the chaperone glucoseregulated protein 78 (GRP78; also known as binding immunoglobulin protein $(\mathrm{BiP})$ or heat shock $70 \mathrm{kDa}$ protein 5 (HSPA5)) (123). When misfolded proteins accumulate in the ER lumen, GRP78 releases from these sensors inducing their activation and downstream signaling (123) leading to ER stress attenuation. When this UPR fails to restore ER homeostasis, usually in conditions of intense or chronic stress, this adaptive UPR will change to a terminal UPR (124), activating pro-apoptotic signaling pathways that lead to cell death (122).

Next to ER stress induced by high demands of protein translation, typical for secretory cells such as beta-cells, environmental factors associated with T1D can trigger 
additional ER stress in beta-cells (125), including coxsackie viral infection, dysglycemia, inflammation, ROS and exposure to chemicals such as streptozotocin and alloxan (125, 126). Apart from inducing beta-cell dysfunction and death, ER stress can also induce PTMs in beta-cells, a process that has been described for thapsigargin induced ER stress, showing increased activation of tissue transglutaminase (TGM2) and PAD, both $\mathrm{Ca}^{2+}$ dependent enzymes $(127,128)$. Also, inflammatory cytokines, which act at least in part through activation of ER stress pathways, were shown to induce citrullination of beta-cell proteins $(15,16,118$, 129) (Figure 3). Interestingly, thapsigargin induced ER stress of human beta-cells leads to increased immunogenicity, as measured by IFN $\gamma$ response of T-cell clones specific for deamidated peptides $(127,128)$.

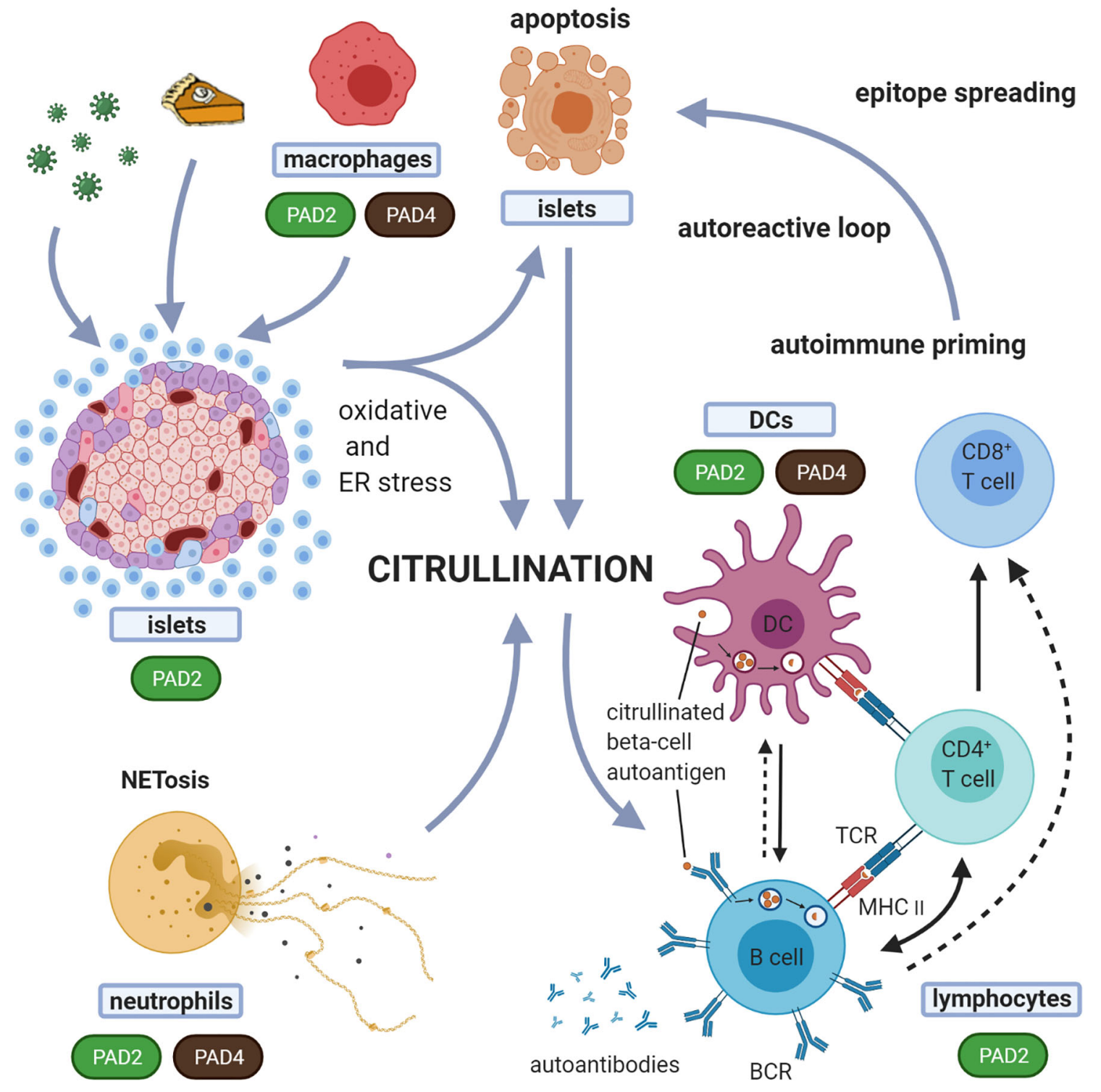

FIGURE 3 | Suggested model for the role of citrullination in the induction of autoreactive responses in T1D. In this proposed model, different forms of cell death, i.e. beta-cell apoptosis and neutrophil death (NETosis), are both implicated in the generation of citrullinated proteins. Any form of environmental stress, such as viruses, inflammatory cytokines or high metabolic demand, can induce oxidative and ER stress in the beta-cells. Oxidative stress induces NETosis. Both beta-cell apoptosis and NETosis have been shown to be involved in T1D initiation and propagation. With expression and activation of PADs during stress conditions, this model suggests that both beta-cells and neutrophils, can induce citrullination. These citrullinated peptides/proteins may be processed by the immune system in different immunogenic ways, forming a source of citrullinated autoantigens. Processing of these modified proteins/peptides by antigen presenting cells, and subsequent presentation to T cells, can in turn trigger several immune responses, including activation of B cells (producing islet autoantibodies) and islet antigenspecific (effector/memory) T cells that can directly kill beta-cells presenting citrullinated islet peptides. The expression of PAD enzymes in beta-cells and neutrophils, and their activation during processes of cellular stress, underscores the relevance of this model. Dashed arrows indicate the potential interactions between $\mathrm{B}$ cells and CD8+ T cells and between B cells and DCs. BCR, B cell receptor; TCR, T-cell receptor. 


\section{CITRULLINATED PROTEINS AND THEIR ROLE IN FUNCTIONAL PATHWAYS}

\section{Epigenetic Role and Biological Functions of Histone Citrullination}

Histones are highly basic proteins, due to the abundance of lysine and arginine residues, assembling with DNA to form nucleosomes. Changes of the positive net charge of histone due to PTMs will affect its electrostatic interaction with chromatin and chromatin accessibility such as phosphorylation, acetylation and citrullination. Of note, citrullinated histones account for about $10 \%$ of all histones in granulocytes (80). Extensive studies demonstrate that PAD catalyzed histone citrullination regulates chromatin structure (condensation versus decondensation), transcriptional regulation, and a variety of biological pathways (Table 3).

Histone $\mathrm{H} 1$ function relies on basic amino acid residues to interact with chromatin and is responsible for the formation of higher-order chromatin structure. Linker histone $\mathrm{H} 1$ citrullinated at residue 54 (H1Cit54; mediated by PAD4) results in activation of several pluripotency genes, such as klf2, Tcl1, Tcfap2c and Kit, due to chromatin decondensation (130, 131). Linker H1Cit54 has also been found in breast cancer cells (138) and in activated neutrophils (41). Relevant to autoimmune syndromes, autoantibodies against citrullinated linker $\mathrm{H} 1$ were found in about $6 \%$ of sera from patients with SLE and SS (41).

The protein core of nucleosomes is composed by core histones, $\mathrm{H} 2 \mathrm{~A}, \mathrm{H} 2 \mathrm{~B}, \mathrm{H} 3$ and $\mathrm{H} 4$. $\mathrm{H} 2 \mathrm{~A}$ function is finely regulated by several PTMs such as acetylation, phosphorylation and methylation $(139,140)$. For example, protein arginine methyltransferase 5 (PRMT5) methylates $\mathrm{H} 2 \mathrm{~A}$ at residue arginine 3 (H2AR3) which serves as an epigenetic activator to promote prostate cancer growth (140). Of note, PAD4-catalyzed citrullinated histone $\mathrm{H} 2 \mathrm{ACit} 3$, is identified in activated neutrophils (77). Compared to other histone proteins, citrullination on histone $\mathrm{H} 3$ has been extensively investigated. Different PAD isozymes catalyze $\mathrm{H} 3$ at different arginine residues and regulate various biological functions. Both PAD1 and PAD2 citrullinate histone $\mathrm{H} 3$ at 2, 8 and 17 residues, H3Cit2,8,17. Citrullination of histone tails at H3R2,8,17 and H4R3 was significantly reduced in 2- and 4-cell embryos after PAD1-morpholino knockout or treatment with a PAD1 specific inhibitor. Deficiency of PAD1 resulted in mouse embryo cells arrested at the 4-cell stage (133). In human mammary epithelium cells (MCF7 cells), PAD2-catalyzed H3R2,8,17 regulates gene expression of pleotropin (PTN) and melanoma associated antigen A12 (MAGEA12) (141). In addition, PAD4-mediated H3Cit8 diminishes the binding of heterochromatin protein $1 \alpha$ (HP $1 \alpha$ ) to methylated histone H3K9 and leads to the suppression of gene expression of human endogenous retroviruses (HERVs) and cytokines in MCF7 cells such as TNF $\alpha$, IL-1A, IL-8, IL-16 and IL-23 (136). PAD2-catalyzed H3Cit26 results in chromatin decondensation and transcriptional activation of estrogen receptor $\alpha$-regulated genes in breast cancer cells (68). Therefore, H3Cit26 is believed to be a potential prognostic biomarker for estrogen receptor positive $(\mathrm{ER}+)$ breast cancer (137). Similar to PAD1-catalyzed H3Cit2,8,17, PAD4-catalyzed H4Cit3 also facilitates early embryo genome transactivation (133). Moreover, PAD4catalyzed H4Cit3 regulates the p53 pathway in apoptosis and in carcinogenesis (81).

\section{Citrullination and Its Role in NETosis}

NETosis is a cellular clearance mechanism distinct from apoptosis, which occurs when neutrophils encounter microorganisms and produce highly modified chromatin webs (142), immobilizing and killing the pathogens. The extruded DNA webs carry a number of bound bactericidal proteins (lactoferrin, elastase, proteinase 3, myeloperoxidase, cathepsin $\mathrm{G}$, etc.) as well as histones and granule proteins. Thus, NETs serve as the first line defense mechanism of innate immunity to protect the host from bacteria, fungi, viruses and protozoa. Emerging evidence reveals that PTMs of histones in neutrophils regulate NETosis, and is associated with the development of autoimmune diseases such as RA, MS and SLE (Table 3). In leukocytes, both PAD2 and PAD4 are expressed (60), with PAD2 being mainly expressed in macrophages and PAD4 in

TABLE 3 | Biological functions of histone citrullination.

\begin{tabular}{|c|c|c|c|}
\hline Histone & $\begin{array}{l}\text { PAD } \\
\text { isozyme }\end{array}$ & Physiological or pathological roles & References \\
\hline $\begin{array}{l}\text { Linker } \\
\text { H1Cit54 }\end{array}$ & PAD4 & $\begin{array}{l}\text { impairs binding to nucleosomal DNA } \\
\text { chromatin decondensation in pluripotent stem cells }\end{array}$ & $(130,131)$ \\
\hline H2ACit3 & PAD4 & occurs in calcium ionophore A23187-stimulated neutrophils & $(77,132)$ \\
\hline H3Cit2,8,17 & PAD1 & facilitates early embryo genome transactivation & $(133)$ \\
\hline H3Cit2,8,17 & PAD2 & regulates lactation associated genes during diestrus in mammary epithelial cells & (69) \\
\hline H3Cit2,8,17 & PAD4 & neutrophil extracellular trap (NET) formation and NETosis & $(134,135)$ \\
\hline H3Cit8 & PAD4 & $\begin{array}{l}\text { transcriptional repression of cytokines genes and human endogenous retroviruses (HERVs) via heterochromatin protein } 1 \alpha \\
(\mathrm{HP} 1 \alpha)\end{array}$ & $(136)$ \\
\hline H3Cit26 & PAD2 & $\begin{array}{l}\text { chromatin decondensation and transcriptional activation of estrogen receptor }(E R) \alpha \text {-regulated gene } \\
\text { potential prognostic biomarker for ER positive }(E R+) \text { breast cancer }\end{array}$ & $\begin{array}{l}(68) \\
(137)\end{array}$ \\
\hline H4Cit3 & PAD4 & $\begin{array}{l}\text { facilitates early embryo genome transactivation } \\
\text { regulates p53 pathway in apoptosis and in carcinogenesis } \\
\text { neutrophil extracellular trap (NET) formation and NETosis }\end{array}$ & $\begin{array}{c}(133) \\
(81) \\
(12-14 \\
134)\end{array}$ \\
\hline
\end{tabular}

$H$, histone; Cit, citrullination; $P A D$, peptidylarginine deiminase. 
monocytes, macrophages, eosinophils and neutrophils $(63,78)$. In neutrophils, citrullination is crucial for NET formation and release (85, 143). Activation of PAD4 leads to hypercitrullination of histones and consequently, decondensation and release of DNA structures coated with neutrophil granule proteins, the NETs $(134,143)$.

NETosis has been indicated as the major autoantigen source in SLE. NETs induce moderate levels of autoantibodies against H3Cit2, 17 and H3Cit26 in MRL/lpr mice, a spontaneous murine model of lupus (32). Moreover, autoantibodies against H1R53 were detected in patients with SLE (41). Recently, abundant citrullinated LL37 was identified in SLE target tissue (skin and kidney) and autoreactive $\mathrm{T}$ cells against both native and citrullinated LL37 were detected in patients with SLE, but not in RA (31). As mentioned earlier, NETosis is enhanced in RA circulating and synovial neutrophils and correlates with ACPA titers (144). H1Cit53 and H3Cit8,17,26 were found in RA and SLE neutrophil NETs (26). One study showed the presence of anti-citrullinated $\mathrm{H} 2 \mathrm{~B}$ antibodies in the anti-CCP2 positive sera from patients with RA (25). In addition, both $\mathrm{H} 3 \mathrm{Cit} 2,8,17$ and citrullinated $\mathrm{H} 4$ from NETs were found as the targets of autoantibodies in patients with RA $(27,145)$.

The involvement of neutrophils and NETosis in T1D has been pointed out by several studies. In the non-obese diabetic (NOD) mouse, a spontaneous mouse model of autoimmune mediated beta-cell destruction and diabetes development, neutrophils and formation of NETs in the pancreas have been shown to be present during early stages of disease development and are required for diabetes development (146). In human T1D, one recent study illustrated a reduction in serum components of NETs [neutrophil elastase (NE) and proteinase 3 (PR3)], consistent with a reduced overall neutrophil count in early onset T1D (147). Conflicting studies report increases in these same NET components in T1D and a positive correlation of the circulating levels of these components with titers of autoantibodies against IA-2 and GAD65 (148). Neutrophil count is decreased in newly diagnosed T1D adult and pediatric patients $(147,149)$ as well as in pre-symptomatic autoantibody individuals (150). This reduction correlates with a decline in beta-cell function (151). Additionally, neutrophils infiltrate the pancreas before disease onset and during disease progression (151) and a significant fraction of these pancreas-infiltrating neutrophils forms NETs (54\% and 50\% in autoantibody-positive and T1D donors, respectively) (151). Relevant to citrullination, protein expression of PAD4 was elevated in neutrophils from patients with T1D and T2D (152). Given all these data indicating that neutrophils and NETosis are involved in diabetes development, the role of PADs and citrullination has also been implicated in T1D through their high expression in neutrophils and essential role in NET formation (Figure 3).

Of note, besides neutrophils, macrophages can release extracellular traps, a process called macrophage extracellular trap formation (METosis). The contribution of METosis in T1D has not been investigated yet, but METosis and PAD4 have been shown to contribute to self-antigen citrullination and ACPA production in autoimmune arthritis (153).

\section{Citrullination in Transcriptional Regulation in Immune Cells}

Besides NETosis, citrullination has other functions in the immune system. In neutrophils, citrullination of NF-kB p65 enhances its nuclear translocation and transcriptional activity, increasing Toll-like receptor (TLR)-induced expression of IL-1 $\beta$ and TNF $\alpha$ (84). Citrullination of the transcription factors GATA3 and ROR $\gamma$ t by PAD2 determines the fate of differentiating Th cells. As such, citrullination of GATA3 on R330 weakens its DNA binding ability, thereby decreasing transcription of Th2 cytokines, attenuating differentiation of Th2 cells. On the other hand, citrullination of ROR $\gamma \mathrm{t}$ on R56,59,77, 90 strengthens its DNA binding ability, increasing the transcription of $\mathrm{IL}-17 \mathrm{~A} / \mathrm{F}$ thereby enhancing the differentiation of Th17 cells (72). Also, citrullination of RNA polymerase II by PAD2 favors an efficient transcription of genes related to cellular proliferation (154). Citrullination can also reduce the potency of chemokines, such as CXCL8, CXCL10, CXCL11 and CXCL12, when compared to their native form (155-157), thereby dampening inflammatory reactions. Additionally, PADs can citrullinate the cytokine TNF $\alpha$ (158), reducing its capacity to stimulate the production of inflammatory chemokines, and TNF $\alpha$ can induce the translocation of PAD4 from the cytosol to the nucleus (38).

\section{Citrullinated Proteins and Their Role in Increasing Antigenicity in T1D}

A primary function of the immune system is to differentiate between self and non-self-proteins. This is achieved by mechanisms that deplete the immune system of lymphocytes that react too strongly to self-antigens being present in the thymus and bone marrow, resulting in tolerance towards selfproteins. For achieving T-cell tolerance, the medullary thymic epithelial cells (mTECs) play an important role in this so-called negative selection (159). This mechanism works effectively for many self-antigens that are expressed in the thymus, through mTEC specific transcriptional regulator AIRE (autoimmune regulator), which drives expression of tissue-restricted genes such as islet specific genes, in the thymus (160). However, whether post-translationally modified self-proteins (Tables 1 and 4) are also expressed in the thymus has not been extensively investigated. If not, this could create a novel autoantigenic proteome for which immune tolerance has not been established in the thymus. This concept, previously described as 'autoantigenesis' is a term described to proteins that 'evolve' and acquire PTMs in a disease related target tissue, during the course of disease development, leading to B and/or autoreactive T-cell responses (4). Evidence for such antigenic modifications was shown in a mouse model of tissue-restricted self-antigen collagen type II, where the PTM reactive $\mathrm{T}$ cells escaped thymic selection (162). In regard to citrullination, it has been shown that PAD2 and PAD4 are expressed in murine mTECs, as measured by qPCR, thereby demonstrating that the prerequisites for negative selection of citrulline-specific $\mathrm{T}$ cells in the thymus are met in C57Bl6 mice (163). However, whether these enzymes are active and able to convert arginine into 
TABLE 4 | Citrullination in T1D,

\begin{tabular}{|c|c|c|}
\hline Target proteins & Affected immune responses & References \\
\hline GAD65 & $\begin{array}{l}\text { target of autoreactive T cells } \\
\left.\text { (HLA-A2 and HLA-DRB } 1^{*} 04: 01\right)\end{array}$ & $(12,13,17)$ \\
\hline IAPP & $\begin{array}{l}\text { target of autoreactive cells } \\
\text { (HLA-DR and HLA-DQ8) }\end{array}$ & $(17,127,161)$ \\
\hline $\mid A-2$ & $\begin{array}{l}\text { potential target of autoreactive T cells } \\
\text { (HLA-A2) }\end{array}$ & (13) \\
\hline GRP78 & $\begin{array}{l}\text { target of autoreactive } T \text { cells } \\
\left.\text { (HLA-DRB } 1^{\star} 04: 01\right) \\
\text { recognized by autoantibody }\end{array}$ & $(15-17)$ \\
\hline IGRP & $\begin{array}{l}\text { potential target of autoreactive } T \text { cells } \\
\text { (HLA-A2) }\end{array}$ & (13) \\
\hline
\end{tabular}

GAD65, glutamic acid decarboxylase 65; IAPP, islet amyloid polypeptide; IA-2, islet antigen-2; GRP78, glucose-regulated protein 78; IGRP, islet-specific glucose-6-phosphatase catalytic subunit-related protein.

citrulline in proteins locally in the thymus, and whether this PAD expression and citrullination capacity is defective in autoimmune strains, such as the NOD mouse, needs further investigation.

In T1D, progressive loss of B and T-cell tolerance to beta-cell specific antigens leads to the destruction of insulin producing beta-cells. A growing number of studies suggest that immune recognition of non-conventional generated peptides/proteins (164), amongst which citrullinated proteins $(12,15,16,165)$ are an important component of that loss of tolerance (Table 4). As such, citrullinated proteins, generated through different stress pathways in beta-cells or neutrophils, as outlined above, could be a source of citrullinated antigens. The expression of PAD enzymes both in beta-cells and neutrophils, their activation during processes of cellular stress, and the role for both betacell apoptosis and NETosis in initiation and propagation of T1D, fit with such view (as schematically shown in Figure 3). The citrullinated peptides/proteins may be processed by the immune system in different immunogenic ways, forming a source of citrullinated autoantigens. Presentation of citrullinated proteins/peptides by antigen presenting cells, and subsequent presentation to $\mathrm{T}$ cells, can trigger several immune responses, including activation of $\mathrm{B}$ cells (producing islet autoantibodies) and islet antigen-specific (effector/memory) $\mathrm{T}$ cells that can directly kill beta-cells presenting citrullinated islet peptides.

Already in 1993 it was shown that the insulin B chain is prone to citrullination in the bacterial model Porphyromonas gingivalis (166), however, only during the last decade several publications described the link between citrullinated beta-cell proteins and autoreactive responses in T1D. In comparison with native peptides, citrullinated peptides present higher binding affinity to HLA-A2 (13) and HLA-DRB1 ${ }^{\star} 04: 01(12,13,167)$, diabetesassociated HLA class I and class II molecules, respectively. Of interest, there is a significant overlap in genetic susceptibility between T1D and RA, with HLA-DRB1*04:01 haplotype being a high-risk haplotype in both diseases. The antigenicity of citrullinated beta-cell antigens that bind to HLA-A2 has been demonstrated by in vitro activation of $\mathrm{CD}^{+} \mathrm{T}$-cell clones, expanded from peripheral blood of HLA-A2 ${ }^{+}$T1D subjects, when cultured with citrullinated peptides derived from IA-2, GAD65 and IGRP (13). One citrullinated peptide of GAD65 with higher binding affinity to HLA-DRB1 ${ }^{\star} 04$ :01 was shown to be recognized by $\mathrm{CD} 4^{+} \mathrm{T}$ cells in the peripheral blood of $\mathrm{T} 1 \mathrm{D}$ patients making use of ex vivo tetramer assays. These $\mathrm{CD} 4^{+} \mathrm{T}$ cells exhibited an antigen-experienced phenotype and were lessor non-responsive to the native form of the epitope (12). Shortly thereafter, Rondas et al. revealed that the ER chaperone GRP78, a major ER chaperone and a key mediator of the UPR pathway, can be citrullinated in INS-1E beta-cells under inflammatory stress, as shown by $2 \mathrm{D}$-Western blotting using a citrulline specific antibody (16). This confirmed earlier proteomic studies showing an increase in PTM for GRP78 in INS-1E after IFN $\gamma$ plus IL1 $\beta$ exposure (129). Citrullinated GRP78 was shown to be immunogenic in diabetes-prone NOD mice with appearance of both autoreactive T cells and autoantibodies (16). Furthermore, it was shown that NOD mice have significantly higher levels of Padi2 mRNA and PAD activity in islets, already at the age of 3 weeks, as compared to normoglycemic C57Bl6 mice $(16,165)$. Absence of IL1 $\beta$ and IFN $\gamma$ expression at this young age, indicated no or minor immune infiltration in the islets, suggesting expression of PAD in the endocrine cells. Further proof for this was provided in a later study, in which $\mathrm{CD}_{4} 5^{+}$islet infiltrating immune cells from 10 -week-old NOD mice were separated from beta and alpha cells by FACS sorting. Expression of Padi2 mRNA was evident in all 3 fractions, with comparable levels in beta-cells and CD45 ${ }^{+}$immune cells (Sodré et al., 2021). Further in vitro studies showed that GRP78 was not only citrullinated upon inflammatory stress, but was also translocated from the ER to the plasma membrane and secreted, at which level the modification of GRP78 was even much more pronounced $(16,118)$. This opens the view that GRP78 may become citrullinated once exposed on the plasma membrane or even after its secretion into the extracellular space. First evidence for a role of citrullinated GRP78 in human T1D, came from the discovery of a CD4 ${ }^{+} \mathrm{T}$-cell clone, isolated from an islet outgrowth of a deceased T1D patient, which recognized citrullinated GRP78 epitope 292-305 (citrullinated at position 297) (17). The same study also showed autoreactive CD $4^{+} \mathrm{T}$ cells against citrullinated IAPP. Direct evidence for citrullination of human GRP78 at arginine residue 510 in cytokine-exposed islets was shown by targeted LC-MS/MS. Using ex vivo tetramer and ELISA assays, the same study showed that a subpopulation of T1D patients presents higher frequencies of $\mathrm{CD} 4^{+} \mathrm{T}$ cells against a citrullinated GRP78 epitope and elevated titers of autoantibodies against citrullinated GRP78 compared to 
healthy subjects (15). Moreover, T-cell responses and autoantibodies against citrullinated GRP78 were more frequent in long-standing T1D than in patients with new-onset T1D. Although the number of patients included in this study is too low to make hard conclusions, these last findings may indicate that immune responses against citrullinated GRP78 contribute to aggravation and/or acceleration of the disease rather than to the initiation of the disease development. Longitudinal studies on at-risk subjects are awaited to further evaluate the exact role of citrullinated antigens in disease staging.

\section{PTMS CAN TRIGGER MORE EXTENSIVE AUTOIMMUNITY, SUCH AS EPITOPE SPREADING}

Several investigators have identified significant differences between the T- and B-cell responses that develop against PTM self-proteins, or cryptic epitopes $(5,13,128,168-170)$. In general, T-cell responses to PTM determinants tend to be specific for the modified peptide only and more rarely crossreact with the unmodified form of the peptide. This concept was originally demonstrated in mice immunized with the isoaspartyl PTM form (isoAsp) of snRNP D lupus autoantigen protein, showing $\mathrm{T}$ cells only proliferate in response to the isoAsp PTM, but are unresponsive to the native (Asp) peptide (168). Alternatively, B-cell and autoantibody responses are often more promiscuous in their binding to both the PTM modified and native self-protein. This phenomenon may be due to the features of antibodies to bind flanking amino acid sequences in both modified and native protein forms. As one example, human SLE and lupus-prone MRL/lpr mice exhibit autoantibodies that bind both isoAsp and Asp forms of histone H2B (171). Moreover, it was demonstrated that autoimmune responses originating from the PTM self-protein diversify in an intraand extra-molecular manner to other self-protein determinants. Therefore, breaking immune tolerance to a PTM self-protein promotes 'epitope spreading', a mechanism where autoimmunity diversifies to epitopes beyond the initial site(s) initiating the response (170). Similarly, there is both intra- and intermolecular B- and T-cell epitope spreading in T1D, SLE, and MS $(168,172)$. Classical studies have described epitope spreading of autoantibody responses with the progression of autoimmune disease (173). As illustrated earlier, apoptotic and necrotic cells are rich sources of PTM-altered self-proteins in various microenvironments, notably conditions of oxidative stress (174) or altered $\mathrm{pH}$ (175).

In both of the collagen-induced arthritis (CIA) and experimental autoimmune encephalomyelitis (EAE) mouse models, citrullination of joint and brain proteins creates neoantigens that become additional targets in epitope spreading of autoimmune responses (172). Citrullination of aggrecan, vimentin, fibrinogen, and type II collagen, known target proteins in RA, initiates epitope spreading by promoting $\mathrm{T}$-cell responses to both citrullinated peptides and the corresponding control peptides (176). In addition, citrullination-induced conformational changes of HSP90 protein unmasks cryptic epitopes to bypass B-cell tolerance in RA (177). Epitope spreading may also apply for citrullinated epitopes in triggering T1D autoimmunity (Figure 3). This is shown for example for citrullinated GRP78, where circulating $\mathrm{CD}^{+} \mathrm{T}$ cells and autoantibodies against both naïve and citrullinated GRP78 peptides are detectable in patients with $\mathrm{T} 1 \mathrm{D}$, suggesting that epitope spreading due to citrullination also occurs in T1D (15).

\section{PTMS IN ANTIGEN PROCESSING AND PRESENTATION}

It is clear that the specificity of ongoing immunity relies on the efficient and accurate antigen processing pathways in epitope generation (178). The presence (or absence) of a PTM of an amino acid residue has been shown to alter the recognition and cleavage by proteases. Additionally, the presence of PTM within an intracellularly processed peptide alters the binding to specific MHC motifs. For example, it has been demonstrated that the absence of $\mathrm{N}$-glycosylation of the neuronal glutamate receptor subunit 3 in Rasmussen's encephalitis, a severe form of pediatric epilepsy, exposes a granzyme B cleavage site. This is just one example of how PTMs may create a novel autoantigen (neoepitope) (179). As another example, most proteases and peptidases do not recognize the peptide linkage connecting isoAsp residues to its neighboring amino acid (180). Finally, Moss and coworkers demonstrated that the deamidation of asparagine residues in tetanus toxin $C$ fragment inhibits the processing by asparagine endopeptidase and results in decreased antigen processing (181). The role of PTMs in antigen processing was examined years ago in studies of model proteins in immunity $(168,182-184)$. An isoaspartylated form of cytochrome $\mathrm{c}$ protein is cleaved differently by cathepsin D compared to the (normal) aspartyl form of the same protein (2). Granzyme B cleavage of autoantigens may also generate new epitopes based on the presence or absence of PTMs in selfprotein (185). Simply put, the presence of PTMs that affect proteolytic enzyme recognition generates a completely new repertoire of peptides during antigen presentation.

Specific subsets of APCs and even the compartments within the cells in which the antigen is processed may shape the type of PTM acquired and whether modified peptide is presented on MHC. Ireland and colleagues (186) demonstrated that B-cell autophagy was required for the generation and presentation of a citrullinated peptide (but not required for the non-modified peptide form). Mamula and others have demonstrated the unique APC functions of $\mathrm{B}$ cells in presenting antigen to $\mathrm{T}$ cells. In particular, it is clear that B cells both present antigens directly, as well as transfer antigens to other APC, such as macrophages and dendritic cells. Thus, different APCs may dictate the self PTM epitopes generated and eventually presented by the immune system (187-189).

It is not fully understood as to how a PTM will affect HLA binding. The 'fit' of the PTM peptide versus native peptide for an 
HLA molecule can vary based on elements including charge and structural changes imposed by PTMs. The HLA binding of various PTM T1D autoantigens has been studied and reviewed by James et al. $(12,13)$. For deamidated and citrullinated residues specifically, the introduction of a negative charge enhances the binding affinity at specific positions in HLA-DR or HLA-DQ molecules. As such, HLA-DRB1*04:01 and DRB1*15:01 prefer citrulline at key positions of their binding motifs, whereas deamidation results in preferential loading onto HLA-DQ molecules (13). This was also shown for citrullinated peptides of vimentin, a RA autoantigen, which has greater affinity for HLA-DRB $1^{\star} 0401$ than the unmodified peptide (190).

Among other autoimmune syndromes, specific PTMs of MBP result in either low, intermediate or a similar affinity for MHC compared with the corresponding wild-type peptide (191). Notably, acetylated MBP peptide (Ac 1-11) is required to incite pathogenic T cells in murine MS, though the unmodified peptide binds MHC with virtually identical kinetics. Similarly, isoaspartic acid residues in cytochrome $\mathrm{c}$ or snRNP D peptides (SLE autoantigens) bind MHC class II in a manner identical to the unmodified peptides (168). However, immune tolerance is maintained to the native peptides. The overall lesson is that PTM self-peptides alter processing and binding by MHC in distinct manner from unmodified (native) peptide.

\section{TARGETING CITRULLINATION: TYPES OF PAD INHIBITORS AND THEIR POTENTIAL AS THERAPEUTIC AGENT IN PRECLINICAL MODELS OF AUTOIMMUNITY}

Given the involvement of citrullination and PAD enzymes in several autoimmune diseases, it has been of great interest to generate compounds targeting PAD activity, i.e. PAD inhibitors. The development of such compounds was made possible with the discovery of the crystal structure of PAD enzymes $(95,192)$. Since then several pan-PAD inhibitors have been developed, with increasing potency, specificity and metabolic stability, of which the 4 most extensively studied irreversible inhibitors are shown in Figure 4. More recent efforts also include the development of specific PAD inhibitors, targeting for instance PAD2 or PAD4, as well as non-covalent reversible inhibitors. For a detailed overview of all developed PAD inhibitors we refer to a recent review specifically focusing on these developments (197).

Considering that PAD dysregulation is associated with several autoimmune diseases (86), numerous studies have evaluated the efficacy, safety and mechanism of action, mainly making use of irreversible pan-PAD inhibitors in animal models of autoimmunity, with promising results. As such, amelioration or even reversal of disease in case of intervention therapies, and delayed initiation or complete protection in case of preventive therapies, was shown in mouse models of RA, MS, SLE, UC, inflammatory bowel disease, and recently also in T1D [reviewed by $(198,199)]$. In general, mechanistic insights from these studies have taught us that targeting PAD making use of panPAD inhibitors effectively decreases protein citrullination levels in the inflamed target tissues, as measured mainly by LC-MS/MS, $\mathrm{PAD}$ activity assays or Western blotting using anti-citrulline $\mathrm{Ab}$ (200-203). Such decreased protein citrullination can evidently have an effect on the autoreactive responses against citrullinated autoantigens, both in terms of autoantibody and T-cell responses, as shown in some published studies $(200,201)$. Next to this, it has become clear that other mechanisms are involved in the observed protection, pointing towards more general effects on innate and adaptive immunity. Not surprisingly, based on the high levels of PAD4 in neutrophils and their important role in histone 3 citrullination and induction of NETosis, as outlined above, in vivo PAD inhibition was shown to reduce NET formation and associated NET-induced tissue damage (204, 205). Other ameliorating disease effects were associated with a decrease in circulating pro-inflammatory cytokine levels, such as IL-6, TNF $\alpha$ and IL-1 $\beta(206,207)$, an increase in Treg populations (200) or a shift in T-lymphocyte populations from Th1/Th17 towards Th2 $(201,208)$. The latter is thought to be mediated through direct inhibition of citrullination of the transcription factors ROR $\gamma \mathrm{T}$ and GATA3 (see also above) (72).

Of interest in the field of T1D, a recent study from the Overbergh laboratory showed a complete protection against diabetes development in the NOD mouse, by daily subcutaneous injections of $\mathrm{BB}-\mathrm{Cl}$-amidine $(1 \mu \mathrm{g} / \mathrm{g}$ body weight) (200). BB-Cl-amidine is a pan-PAD inhibitor that, similar to its mother compound (Cl-amidine), irreversibly inactivates $\mathrm{PAD}$ enzymes through covalent modification of an important cysteine for the activity of the enzymes (209). Remarkably, diabetes protection was observed when starting treatment at 8 weeks of age, a time point at which insulitis is already ongoing, but hyperglycemia has not developed (200). This observation tempts us to conclude that citrullination may play a role in amplification of the disease rather than being an initial trigger in breaking immune tolerance. $\mathrm{BB}-\mathrm{Cl}$-amidine treatment was associated with decreased citrullination levels in the pancreas as demonstrated by LC-MS/MS and western blotting with anticitrulline $\mathrm{Ab}$, as well as decreased levels of circulating autoantibodies against citrullinated GRP78, a known citrullinated autoantigen in T1D (as outlined above, Table 4) $(15,16)$. These findings confirm the effective direct action of BB$\mathrm{Cl}$-amidine on inhibition of PAD activity. Furthermore, bonemarrow derived neutrophils isolated from $\mathrm{BB}-\mathrm{Cl}$-amidine treated mice showed less potential for spontaneous NET formation when compared to the control group. Disease protection was associated with preservation of pancreatic insulin levels, although only a marginal reduction in insulitis was observed, suggesting a less aggressive form of insulitis, in line with reduced $\mathrm{CD}^{+}$effector memory $\mathrm{T}$ cells and reduced IFN $\gamma$ producing $\mathrm{T}$ cells in the pancreas infiltrates. In the periphery, a shift from Th1 towards Th2 cytokine levels and increased frequency of regulatory $\mathrm{T}$ cells was observed.

Taken together, the promising results obtained with panPAD inhibition in the NOD mouse, as well as in other autoimmune mouse models, indicate that disease protection is 


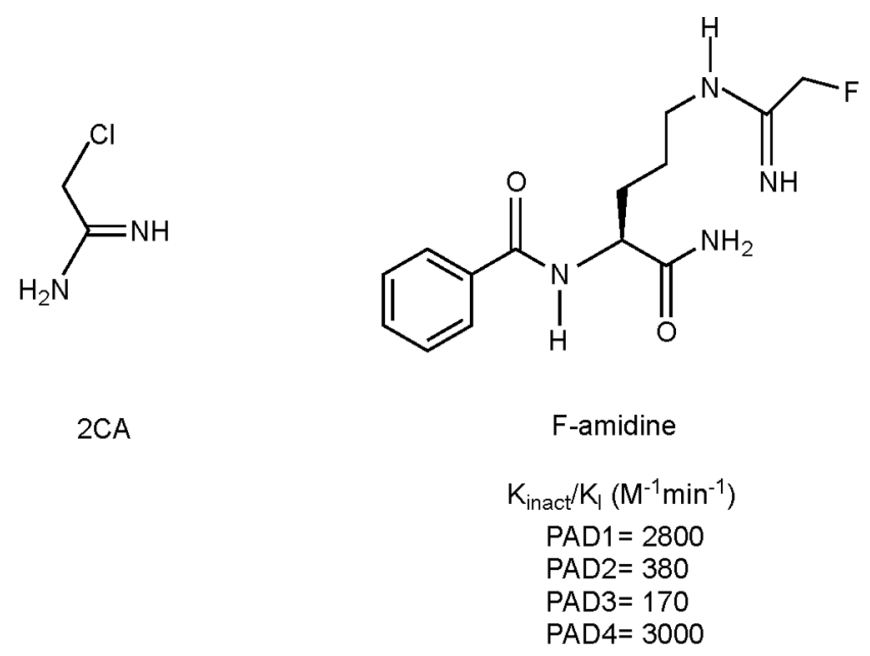

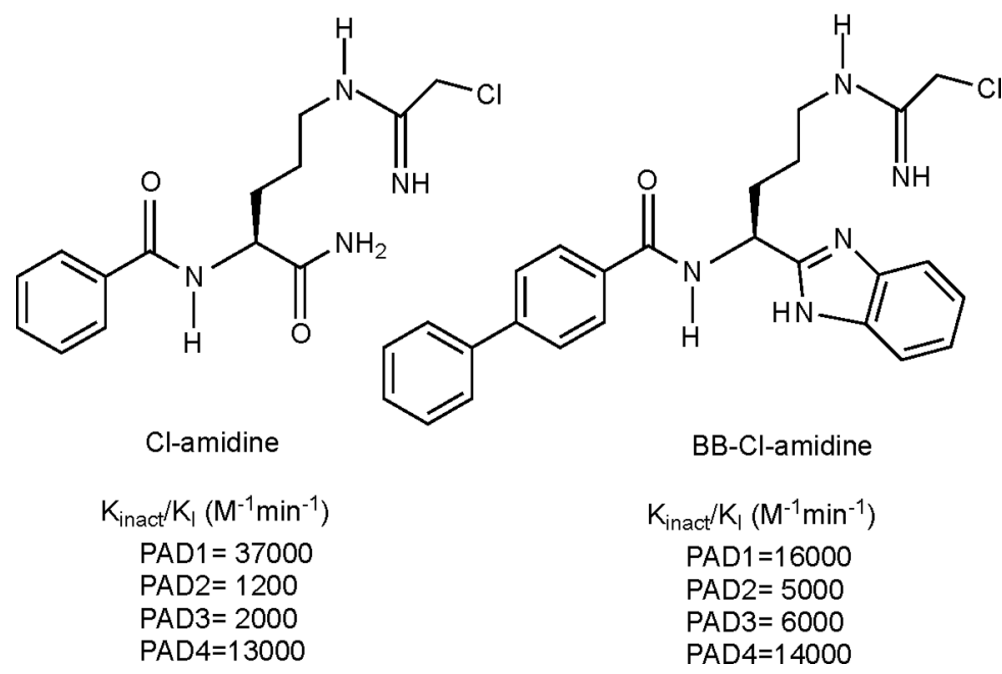

FIGURE 4 | Structures and $\mathrm{k}_{\text {inact }} / \mathrm{K}_{1}$ values for some irreversible pan-PAD inhibitors. 2CA (193), F-amidine, Cl-amidine (194) and BB-Cl-amidine (195). $\mathrm{K}_{\text {inact }} / \mathrm{K}_{1}$ values have been described as the best measure of potencies for irreversible inhibitors (196). $\mathrm{K}_{\text {inact }}$ : rate of enzyme inactivation; $\mathrm{K}_{1}$ : inhibition constant.

mediated by effective inhibition of citrullination in the target inflamed tissue, leading to decreased autoreactive responses. This further underscores the observation that citrullination is not a specific disease-related event, but rather an inflammationdependent process occurring preferentially in autoimmune target tissues (210). Next to this, the extensive data in different preclinical autoimmune models indicate that pan-PAD inhibitors also have more general effects on immune cells, thereby dampening inflammation and reshaping the immune response towards tolerance. Whereas this may be an additional benefit for the use of PAD inhibitors, caution is also warranted. Since pan-PAD inhibitors act both intra- and extracellularly, and citrullination is important in many physiological processes, such as epigenetic and transcriptional regulation, as outlined above, the concern about possible adverse side effects cannot be neglected. Therefore, more studies are needed to evaluate more specifically potential adverse effects before translating to the human situation. Of interest in this regard is the development of isozyme-specific PAD inhibitors, which are hoped to still be protective in disease development, but allow physiological citrullination to occur. Great progress has been made in this path, with development of a high number of PAD specific inhibitors. For instance, a PAD1-selective inhibitor (211), DCl-amidine, and a specific PAD2 inhibitor (194), AFM30a, both based on the structure of $\mathrm{Cl}$-amidine. PAD4-specific inhibitors include TDFA (212) and GSK199, with GSK199 being a reversible PAD4 inhibitor that targets the apo state of the enzyme, showing potent inhibition of PAD4 at low concentration of calcium (0.2mM) (143). GSK199 has been demonstrated to be effective in blocking murine arthritis (213), however, more studies are needed to evaluate the efficacy and safety of such specific inhibitors. 


\section{CONCLUDING REMARKS}

In summary, we have attempted to illustrate and summarize various biochemical, immunologic, and transcriptional aspects of citrulline modifications. How citrullination alters these unique biologic processes in spontaneous autoimmune syndromes are beyond the prediction of simple genetics or other stochastic factors. Citrullination, as well as many other PTMs and cellular pathways, are affected by inflammatory cytokines and reactive oxygen species that inhabit the tissue microenvironments in T1D and other autoimmune diseases. More indirect pathways are also affected by citrulline modified proteins, including downstream transcriptional events. The emerging technologies of detecting citrulline modifications as well as other PTMs in proteomics and tissue analyses will undoubtable change the landscape of autoimmunity in the coming months and years. These analyses, notably the presence of serum anti-citrulline autoantibodies, have already contributed to the clinical diagnoses and assessment of the progression of disease, and tissue pathology. With the identification of specific biomarkers and an understanding of their origins, the field will now have potential therapeutic pathways as targets to modify these autoimmune diseases, including the reducing tissue inflammation and use of inhibitors of citrullination prior to destruction of the pancreatic islets.

\section{REFERENCES}

1. Uy R, Wold F. Posttranslational Covalent Modification of Proteins. Science (1977) 198:890-6. doi: 10.1126/science.337487

2. Doyle HA, Gee RJ, Mamula MJ. Altered Immunogenicity of Isoaspartate Containing Proteins. Autoimmunity (2007) 40:131-7. doi: 10.1080/ 08916930601165180

3. Yang ML, Gee AJP, Gee RJ, Zurita-Lopez CI, Khare S, Clarke SG, et al. Lupus Autoimmunity Altered by Cellular Methylation Metabolism. Autoimmunity (2013) 46:21-31. doi: 10.3109/08916934.2012.732133

4. Doyle HA, Mamula MJ. Autoantigenesis: The Evolution of Protein Modifications in Autoimmune Disease. Curr Opin Immunol (2012) 24:112-8. doi: 10.1016/j.coi.2011.12.003

5. Doyle HA, Yang ML, Raycroft MT, Gee RJ, Mamula MJ. Autoantigens: Novel Forms and Presentation to the Immune System. Autoimmunity (2014) 47:220-33. doi: 10.3109/08916934.2013.850495

6. Callebaut A, Derua R, Vig S, Delong T, Mathieu C, Overbergh L. Identification of Deamidated Peptides in Cytokine-Exposed MIN6 Cells Through LC-MS/MS Using a Shortened Digestion Time and Inspection of MS2 Spectra. J Proteome Res (2021) 20:1405-14. doi: 10.1021/acs.jproteome.0c00801

7. Fearon WR. The Carbamido Diacetyl Reaction: A Test for Citrulline. Biochem J (1939) 33:902-7. doi: 10.1042/bj0330902

8. Nicholas AP, Thompson PR, Bhattacharya SK. Protein Deimination in Human Health and Disease. Springer International Publishing (2017). doi: 10.1007/978-3-319-58244-3

9. György B, Tóth E, Tarcsa E, Falus A, Buzás EI. Citrullination: A Posttranslational Modification in Health and Disease. Int J Biochem Cell Biol (2006) 38:1662-77. doi: 10.1016/j.biocel.2006.03.008

10. Takahara H, Okamoto H, Sugawara K. Calcium-Dependent Properties of Peptidylarginine Deiminase From Rabbit Skeletal Muscle. Agric Biol Chem (1986) 50:2899-904. doi: 10.1080/00021369.1986.10867830

11. Darrah E, Andrade F. Rheumatoid Arthritis and Citrullination. Curr Opin Rheumatol (2018) 176:139-48. doi: 10.1097/BOR.0000000000000452

12. McGinty JW, Chow IT, Greenbaum C, Odegard J, Kwok WW, James EA. Recognition of Posttranslationally Modified GAD65 Epitopes in Subjects With Type 1 Diabetes. Diabetes (2014) 63:3033-40. doi: 10.2337/db13-1952

\section{AUTHOR CONTRIBUTIONS}

M-LY, FS, MM, and LO conceived the concept and co-wrote the manuscript. All authors contributed to the article and approved the submitted version.

\section{FUNDING}

Research in this area in the LO lab is supported by JDRF (1-SRA2019-809-S-B) and by IMI2-JU under grant agreement No 115797 (INNODIA) and No 945268 (INNODIA HARVEST). This Joint Undertaking receives support from the Union's Horizon 2020 research and innovation program and "EFPIA", "JDRF" and "The Leona M. and Harry B. Helmsley Charitable Trust". M-LY and MM were supported by the JDRF (1-SRA2020-977-S-B and 1-SRA-2020-981-S-B), NIH: AI48120-13 and DK104205-01.

\section{ACKNOWLEDGMENTS}

Figures 2 and 3 were created with BioRender. We thank Conny Gysemans (CEE) for help with Figure 3.

13. McGinty JW, Marré ML, Bajzik V, Piganelli JD, James EA. T Cell Epitopes and Post-Translationally Modified Epitopes in Type 1 Diabetes. Curr Diabetes Rep (2015) 15:1-14. doi: 10.1007/s11892-015-0657-7

14. Reijonen H, Novak EJ, Kochik S, Heninger A, Liu AW, Kwok WW, et al. Detection of GAD65-specific T-Cells by Major Histocompatibility Complex Class II Tetramers in Type 1 Diabetic Patients and At-Risk Subjects. Diabetes (2002) 51:1375-82. doi: 10.2337/diabetes.51.5.1375

15. Buitinga M, Callebaut A, Marques Câmara Sodré F, Crèvecoeur I, BlahnikFagan G, Yang M, et al. Inflammation-Induced Citrullinated GlucoseRegulated Protein 78 Elicits Immune Responses in Human Type 1 Diabetes. Diabetes (2018) 67:2337-48. doi: 10.2337/db18-0295

16. Rondas D, Crèvecoeur I, D'Hertog W, Ferreira GB, Staes A, Garg AD, et al. Citrullinated Glucose-Regulated Protein 78 Is an Autoantigen in Type 1 Diabetes. Diabetes (2015) 64:573-86. doi: 10.2337/db14-0621

17. Babon JAB, Denicola ME, Blodgett DM, Crèvecoeur I, Buttrick TS, Maehr R, et al. Analysis of Self-Antigen Specificity of Islet-Infiltrating T Cells From Human Donors With Type 1 Diabetes. Nat Med (2016) 22:1482-7. doi: $10.1038 / \mathrm{nm} .4203$

18. Denroche HC, Verchere CB. IAPP and Type 1 Diabetes: Implications for Immunity, Metabolism and Islet Transplants. J Mol Endocrinol (2018) 60: R57-75. doi: 10.1530/JME-17-0138

19. Takizawa $Y$, Suzuki A, Sawada T, Ohsaka M, Inoue T, Yamada R, et al. Citrullinated Fibrinogen Detected as a Soluble Citrullinated Autoantigen in Rheumatoid Arthritis Synovial Fluids. Ann Rheum Dis (2006) 65:1013-20. doi: $10.1136 /$ ard.2005.044743

20. Raijmakers R, van Beers JJBC, El-Azzouny M, Visser NFC, Božič B, Pruijn GJM, et al. Elevated Levels of Fibrinogen-Derived Endogenous Citrullinated Peptides in Synovial Fluid of Rheumatoid Arthritis Patients. Arthritis Res Ther (2012) 14:1-10. doi: 10.1186/ar3840

21. Zhao X, Okeke NL, Sharpe O, Batliwalla FM, Lee AT, Ho PP, et al. Circulating Immune Complexes Contain Citrullinated Fibrinogen in Rheumatoid Arthritis. Arthritis Res Ther (2008) 10:1-13. doi: 10.1186/ar2478

22. Feitsma AL, Van Der Voort EIH, Franken KLMC, El Bannoudi HE, Elferink BG, Drijfhout JW, et al. Identification of Citrullinated Vimentin Peptides as T Cell Epitopes in HLA-DR4-Positive Patients With Rheumatoid Arthritis. Arthritis Rheum (2010) 62:117-25. doi: 10.1002/art.25059 
23. Tilleman K, Van Steendam K, Cantaert T, De Keyser F, Elewaut D, Deforce D. Synovial Detection and Autoantibody Reactivity of Processed Citrullinated Isoforms of Vimentin in Inflammatory Arthritides. Rheumatology (2008) 47:597-604. doi: 10.1093/rheumatology/ken077

24. Steendam KV, Tilleman K, Ceuleneer M, Keyser F, Elewaut D, Deforce D. Citrullinated Vimentin as an Important Antigen in Immune Complexes From Synovial Fluid of Rheumatoid Arthritis Patients With Antibodies Against Citrullinated Proteins. Arthritis Res Ther (2010) 12:R132. doi: $10.1186 / \mathrm{ar} 3070$

25. Sohn DH, Rhodes C, Onuma K, Zhao X, Sharpe O, Gazitt T, et al. Local Joint Inflammation and Histone Citrullination in a Murine Model of the Transition From Preclinical Autoimmunity to Inflammatory Arthritis. Arthritis Rheumatol (2015) 67:2877-87. doi: 10.1002/art.39283

26. Chapman EA, Lyon M, Simpson D, Mason D, Beynon RJ, Moots RJ, et al. Caught in a Trap? Proteomic Analysis of Neutrophil Extracellular Traps in Rheumatoid Arthritis and Systemic Lupus Erythematosus. Front Immunol (2019) 10:423. doi: 10.3389/fimmu.2019.00423

27. Janssen KMJ, de Smit MJ, Withaar C, Brouwer E, van Winkelhoff AJ, Vissink A, et al. Autoantibodies Against Citrullinated Histone H3 in Rheumatoid Arthritis and Periodontitis Patients. J Clin Periodontol (2017) 44:577-84. doi: $10.1111 /$ jcpe. 12727

28. Yoshida M, Tsuji M, Kurosaka D, Kurosaka D, Yasuda J, Ito Y, et al. Autoimmunity to Citrullinated Type II Collagen in Rheumatoid Arthritis. Mod Rheumatol (2006) 16:276-81. doi: 10.1007/s10165-006-0498-y

29. Gerstner C, Dubnovitsky A, Sandin C, Kozhukh G, Uchtenhagen H, James EA, et al. Functional and Structural Characterization of a Novel HLADRB1 ${ }^{*} 04$ : 01-Restricted $\alpha$-Enolase T Cell Epitope in Rheumatoid Arthritis. Front Immunol (2016) 7:494. doi: 10.3389/fimmu.2016.00494

30. Shoda H, Fujio K, Shibuya M, Okamura T, Sumitomo S, Okamoto A, et al. Detection of Autoantibodies to Citrullinated BiP in Rheumatoid Arthritis Patients and Pro-Inflammatory Role of Citrullinated BiP in CollagenInduced Arthritis. Arthritis Res Ther (2011) 13(R191):1-12. doi: 10.1186/ ar3520

31. Lande R, Palazzo R, Gestermann N, Jandus C, Falchi M, Spadaro F, et al. Native/Citrullinated LL37-Specific T-Cells Help Autoantibody Production in Systemic Lupus Erythematosus. Sci Rep (2020) 10:1-14. doi: 10.1038/ s41598-020-62480-3

32. Liu CL, Tangsombatvisit S, Rosenberg JM, Mandelbaum G, Gillespie EC, Gozani OP, et al. Specific Post-Translational Histone Modifications of Neutrophil Extracellular Traps as Immunogens and Potential Targets of Lupus Autoantibodies. Arthritis Res Ther (2012) 14:1-14. doi: 10.1186/ ar3707

33. Moscarello MA, Wood DD, Ackerley C, Boulias C. Myelin in Multiple Sclerosis Is Developmentally Immature. J Clin Invest (1994) 94:164-54. doi: 10.1172/JCI117300

34. Wood DD, Bilbao JM, Connors PO, Moscarello MA. Acute Mul Tiple Sclerosis (Marburg Type) Is Associated With Developmentally Immature Myelin Basic Protein. Ann Neurol (1996) 40:18-24. doi: 10.1002/ ana.410400106

35. Deraos G, Chatzantoni K, Matsoukas M, Tselios T, Deraos S, Katsara M, et al. Citrullination of Linear and Cyclic Altered Peptide Ligands From Myelin Basic Protein (Mbp 87 - 99) Epitope Elicits a Th1 Polarized Response by T Cells Isolated From Multiple Sclerosis Patients: Implications in Triggering Disease. J Med Chem (2008) 51:7834-42. doi: 10.1021/ jm800891n

36. Bradford CM, Ramos I, Cross AK, Haddock G, McQuaid S, Nicholas AP, et al. Localisation of Citrullinated Proteins in Normal Appearing White Matter and Lesions in the Central Nervous System in Multiple Sclerosis. J Neuroimmunol (2014) 273:85-95. doi: 10.1016/j.jneuroim.2014.05.007

37. Faigle W, Cruciani C, Wolski W, Roschitzki B, Puthenparampil M, TomasOjer P, et al. Brain Citrullination Patterns and T Cell Reactivity of Cerebrospinal Fluid-Derived CD4+ T Cells in Multiple Sclerosis. Front Immunol (2019) 10:540. doi: 10.3389/fimmu.2019.00540

38. Mastronardi FG, Wood DD, Mei J, Raijmakers R, Tseveleki V, Dosch HM, et al. Increased Citrullination of Histone $\mathrm{H} 3$ in Multiple Sclerosis Brain and Animal Models of Demyelination: A Role for Tumor Necrosis FactorInduced Peptidylarginine Deiminase 4 Translocation. J Neurosci (2006) 26:11387-96. doi: 10.1523/JNEUROSCI.3349-06.2006
39. Ishida-Yamamoto A, Senshu T, Takahashi H, Akiyama K, Nomura K, Iizuka H. Decreased Deiminated Keratin K1 in Psoriatic Hyperproliferative Epidermis. J Invest Dermatol (2000) 114:701-5. doi: 10.1046/j.15231747.2000.00936.x

40. Senshu T, Akiyama K, Kan S, Asaga H, Ishigami A, Manabe M. Detection of Deiminated Proteins in Rat Skin: Probing With a Monospecific Antibody After Modification of Citrulline Residues. J Invest Dermatol (1995) 105:1639. doi: 10.1111/1523-1747.ep12317070

41. Dwivedi N, Neeli I, Schall N, Wan H, Desiderio DM, Csernok E, et al. Deimination of Linker Histones Links Neutrophil Extracellular Trap Release With Autoantibodies in Systemic Autoimmunity. FASEB J (2014) 28:284051. doi: 10.1096/fj.13-247254

42. Nezos A, Cinoku I, Mavragani CP, Moutsopoulos HM. Antibodies Against Citrullinated Alpha Enolase Peptides in Primary Sjogren's Syndrome. Clin Immunol (2017) 183:300-3. doi: 10.1016/j.clim.2017.09.012

43. Alessandri C, Agmon-Levin N, Conti F, Perricone C, Ortona E, Pendolino $\mathrm{M}$, et al. Anti-Mutated Citrullinated Vimentin Antibodies in Antiphospholipid Syndrome: Diagnostic Value and Relationship With Clinical Features. Immunol Res (2017) 65:524-31. doi: 10.1007/s12026017-8899-x

44. Mortensen JH, Godskesen E, Dam M, Haaften TV, Klinge G, Olinga P, et al. Fragments of Citrullinated and MMP- Degraded Vimentin and MMPdegraded Type III Collagen Are Novel Serological Biomarkers to Differentiate Crohn's Disease From Ulcerative Colitis. J Crohn's Colitis (2015) 9:863-72. doi: 10.1093/ecco-jcc/jjv123

45. Al-Jarallah K, Shehab D, Al-Attiyah R, Al-Azmi W, Al-Fadli A, Zafar Haider M, et al. Antibodies to Mutated Citrullinated Vimentin and Anti-Cyclic Citrullinated Peptide Antibodies in Inflammatory Bowel Disease and Related Arthritis. Inflammation Bowel Dis (2012) 18:1655-62. doi: 10.1002/ibd.21937

46. Wang F, Chen F, Gao W, Wang H, Zhao N, Xu M, et al. Identification of Citrullinated Peptides in the Synovial Fluid of Patients With Rheumatoid Arthritis Using LC-MALDI-TOF/TOF. Clin Rheumatol (2016) 35:2185-94. doi: 10.1007/s10067-016-3247-4

47. Aletaha D, Neogi T, Silman AJ, Funovits J, Felson DT, Bingham CO, et al. 2010 Rheumatoid Arthritis Classification Criteria: An American College of Rheumatology/European League Against Rheumatism Collaborative Initiative. Arthritis Rheum (2010) 62:2569-81. doi: 10.1002/art.27584

48. Rantapää-Dahlqvist S, Jong BAW De, Berglin E, Stenlund H, Sundin U. Venrooij WJ Van. Antibodies Against Cyclic Citrullinated Peptide and IgA Rheumatoid Factor Predict the Development of Rheumatoid Arthritis. Arthritis Rheum (2003) 48:2741-9. doi: 10.1002/art.11223

49. Meyer O, Labarre C, Dougados M, Goupille P, Cantagrel A, Dubois A, et al. Anticitrullinated Protein/Peptide Antibody Assays in Early Rheumatoid Arthritis for Predicting Five Year Radiographic Damage. Ann Rheum Dis (2003) 62:120-6. doi: 10.1136/ard.62.2.120

50. Molano-González N, Olivares-Martínez E, Anaya JM, Hernández-Molina G. Anti-Citrullinated Protein Antibodies and Arthritis in Sjögren's Syndrome: A Systematic Review and Meta-Analysis. Scand J Rheumatol (2019) 48:15763. doi: 10.1080/03009742.2018.1469164

51. Chavanas S, Méchin MC, Takahara H, Kawada A, Nachat R, Serre G, et al. Comparative Analysis of the Mouse and Human Peptidylarginine Deiminase Gene Clusters Reveals Highly Conserved Non-Coding Segments and a New Human Gene, PADI6. Gene (2004) 330:19-27. doi: $10.1016 /$ j.gene.2003.12.038

52. Rogers GE, Harding HWJ, Llewellyn-Smith IJ. The Origin of CitrullineContaining Proteins in the Hair Follicle and the Chemical Nature of Trichohyalin, an Intracellular Precursor. BBA - Protein Struct (1977) 495:159-75. doi: 10.1016/0005-2795(77)90250-1

53. Fujisaki M, Sugawara K. Properties Epidermis of Peptidylarginine of Newborn Rats. J Biochem (1981) 89:257-63. doi: 10.1093/ oxfordjournals.jbchem.a133189

54. Amin B, Voelter W. Human Deiminases: Isoforms, Substrate Specificities, Kinetics, and Detection. Prog Chem Org Nat Prod (2017) 106:203-40. doi: 10.1007/978-3-319-93506-5

55. Terakawa H, Takahara H, Sugawara K. Three Types of Mouse Peptidylarginine Deiminase: Characterization and Tissue Distribution J Biochem (1991) 110:661-6. doi: 10.1093/oxfordjournals.jbchem.a123636 
56. Nachat R, Méchin MC, Charveron M, Serre G, Constans J, Simon M. Peptidylarginine Deiminase Isoforms Are Differentially Expressed in the Anagen Hair Follicles and Other Human Skin Appendages. J Invest Dermatol (2005) 125:34-41. doi: 10.1111/j.0022-202X.2005.23763.x

57. Nachat R, Méchin MC, Takahara H, Chavanas S, Charveron M, Serre G, et al. Peptidylarginine Deiminase Isoforms 1-3 Are Expressed in the Epidermis and Involved in the Deimination of $\mathrm{K} 1$ and Filaggrin. $J$ Invest Dermatol (2005) 124:384-93. doi: 10.1111/j.0022-202X.2004.23568.x

58. Senshu T, Kan S, Ogawa H, Manabe M, Asaga H. Preferential Deimination of Keratin K1 and Filaggrin During the Terminal Differentiation of Human Epidermis. Biochem Biophys Res Commun (1996) 719:712-9. doi: 10.1006/ bbrc. 1996.1240

59. Ishida-Yamamoto A, Senshu T, Eady RAJ, Takahashi H, Shimizu H, Akiyama M, et al. Sequential Reorganization of Cornified Cell Keratin Filaments Involving Filaggrin-Mediated Compaction and Keratin 1 Deimination. J Invest Dermatol (2002) 118:282-7. doi: 10.1046/j.0022202x.2001.01671.x

60. Beers JJBCV, Zendman AJW, Raijmakers R, Stammen-vogelzangs J, Pruijn GJM. Peptidylarginine Deiminase Expression and Activity in PAD2 KnockOut and PAD4-Low Mice. Biochimie (2013) 95:299-308. doi: 10.1016/ j.biochi.2012.09.029

61. Takahara H, Tsuchida M, Kusubata M, Akutsu K, Tagami Sugawara SK. Peptidylarginine Deiminase of the Mouse. Distribution, Properties, and Immunocytochemical Localization. J Biol Chem (1989) 264:13361-8. doi: 10.1016/S0021-9258(18)51637-9

62. Watanabe K, Akiyama K, Hikichi K, Ohtsuka R, Okuyama A, Senshu T. Combined Biochemical and Immunochemical Comparison of Peptidylarginine Deiminases Present in Various Tissues. BBA - Gen Subj (1988) 966:375-83. doi: 10.1016/0304-4165(88)90088-8

63. Vossenaar ER, Radstake TRD, Van Der Heijden A, Van Mansum MAM, Dieteren C, De Rooij DJ, et al. Expression and Activity of Citrullinating Peptidylarginine Deiminase Enzymes in Monocytes and Macrophages. Ann Rheum Dis (2004) 63:373-81. doi: 10.1136/ard.2003.012211

64. Zhou Y, Chen B, Mittereder N, Chaerkady R, Strain M, An LL, et al. Spontaneous Secretion of the Citrullination Enzyme PAD2 and Cell Surface Exposure of PAD4 by Neutrophils. Front Immunol (2017) 8:1200. doi: 10.3389/fimmu.2017.01200

65. Liu Y, Lightfoot YL, Seto N, Carmona-Rivera C, Moore E, Goel R, et al. Peptidylarginine Deiminases 2 and 4 Modulate Innate and Adaptive Immune Responses in TLR-7-Dependent Lupus. JCI Insight (2018) 3:1-21. doi: 10.1172 /jci.insight.124729

66. Lamensa JWE, Moscarello MA. Deimination of Human Myelin Basic Protein by a Peptidylarginine Deiminase From Bovine Brain. J Neurochem (1993) 61:987-96. doi: 10.1111/j.1471-4159.1993.tb03612.x

67. Darrah E, Rosen A, Giles JT, Andrade F. Peptidylarginine Deiminase 2, 3 and 4 Have Distinct Specificities Against Cellular Substrates: Novel Insights Into Autoantigen Selection in Rheumatoid Arthritis. Ann Rheum Dis (2012) 71:92-8. doi: 10.1136/ard.2011.151712

68. Zhang X, Bolt M, Guertin MJ, Chen W, Zhang S, Cherrington BD, et al. Peptidylarginine Deiminase 2-Catalyzed Histone H3 Arginine 26 Citrullination Facilitates Estrogen Receptor $\alpha$ Target Gene Activation. Proc Natl Acad Sci (2012) 109:13331-6. doi: 10.1073/pnas

69. Damgaard D, Bawadekar M, Senolt L, Stensballe A, Shelef MA, Nielsen CH. Relative Efficiencies of Peptidylarginine Deiminase 2 and 4 in Generating Target Sites for Anti-Citrullinated Protein Antibodies in Fibrinogen, AlphaEnolase and Histone H3. PloS One (2018) 13:1-14. doi: 10.1371/ journal.pone.0203214

70. Inagaki M, Takahara H, Nishi Y, Sugawara K, Sato C. Ca2+-Dependent Deimination-Induced Dissembly of Intermediate Filaments Involves Specific Modification of the Amino-Terminal Head Domain. J Biol Chem (1989) 264:18119-27. doi: 10.1016/S0021-9258(19)84685-9

71. Wang S, Wang Y. Peptidylarginine Deiminases in Citrullination, Gene Regulation, Health and Pathogenesis. Biochim Biophys Acta - Gene Regul Mech (2013) 1829:1126-35. doi: 10.1016/j.bbagrm.2013.07.003

72. Sun B, Chang HH, Salinger A, Tomita B, Bawadekar M, Holmes CL, et al. Reciprocal Regulation of Th2 and Th17 Cells by PAD2-Mediated Citrullination. JCI Insight (2019) 4:e129687. doi: 10.1172/jci.insight.129687
73. Vossenaar ER, Zendman AJW, Van Venrooij WJ, Pruijn GJM. PAD, a Growing Family of Citrullinating Enzymes: Genes, Features and Involvement in Disease. BioEssays (2003) 25:1106-18. doi: 10.1002/bies.10357

74. Ishigami A, Ohsawa T, Hiratsuka M, Taguchi H, Kobayashi S, Saito Y, et al. Abnormal Accumulation of Citrullinated Proteins Catalyzed by Peptidylarginine Deiminase in Hippocampal Extracts From Patients With Alzheimer's Disease. J Neurosci Res (2005) 80:120-8. doi: 10.1002/jnr.20431

75. Jang B, Jin JK, Jeon YC, Cho HJ, Ishigami A, Choi KC, et al. Involvement of Peptidylarginine Deiminase-Mediated Post-Translational Citrullination in Pathogenesis of Sporadic Creutzfeldt-Jakob Disease. Acta Neuropathol (2010) 119:199-210. doi: 10.1007/s00401-009-0625-x

76. KP U, Subramanian V, Nicholas AP, Thompson PR, Ferretti P. Modulation of Calcium-Induced Cell Death in Human Neural Stem Cells by the Novel Peptidylarginine Deiminase-AIF Pathway. Biochim Biophys Acta - Mol Cell Res (2014) 1843:1162-71. doi: 10.1016/j.bbamcr.2014.02.018

77. Nakashima K, Hagiwara T, Yamada M. Nuclear Localization of Peptidylarginine Deiminase V and Histone Deimination in Granulocytes. J Biol Chem (2002) 277:49562-8. doi: 10.1074/jbc.M208795200

78. Asaga H, Nakashima K, Senshu T, Ishigami A, Yamada M. Immunocytochemical Localization of Peptidylarginine Deiminase in Human Eosinophils and Neutrophils. J Leukoc Biol (2001) 70:46-51. doi: $10.1189 / \mathrm{jlb} .70 .1 .46$

79. Acharya NK, Nagele EP, Han M, Coretti NJ, Demarshall C, Kosciuk MC, et al. Neuronal PAD4 Expression and Protein Citrullination : Possible Role in Production of Autoantibodies Associated With Neurodegenerative Disease. J Autoimmun (2012) 38:369-80. doi: 10.1016/j.jaut.2012.03.004

80. Hagiwara T, Nakashima K, Hirano H, Senshu T, Yamada M. Deimination of Arginine Residues in Nucleophosmin/B23 and Histones in HL-60 Granulocytes. Biochem Biophys Res Commun (2002) 290:979-83. doi: 10.1006/bbrc.2001.6303

81. Tanikawa C, Espinosa M, Suzuki A, Masuda K, Yamamoto K, Tsuchiya E, et al. Regulation of Histone Modification and Chromatin Structure by the P53-PADI4 Pathway. Nat Commun (2012) 3:676. doi: 10.1038/ncomms1676

82. Chang X, Yamada R, Sawada T, Suzuki A, Kochi Y, Yamamoto K. The Inhibition of Antithrombin by Peptidylarginine Deiminase 4 may Contribute to Pathogenesis of Rheumatoid Arthritis. Rheumatology (2005) 44:293-8. doi: 10.1093/rheumatology/keh473

83. Guo Q, Fast W. Citrullination of Inhibitor of Growth 4 (ING4) by Peptidylarginine Deminase 4 (PAD4) Disrupts the Interaction Between ING4 and p53*. J Biol Chem (2011) 286:17069-78. doi: 10.1074/ jbc.M111.230961

84. Sun B, Dwivedi N, Bechtel TJ, Paulsen JL, Muth A, Bawadekar M, et al. Citrullination of NF-kb p65 Promotes Its Nuclear Localization and TLRInduced Expression of IL-1 $\beta$ and Tnfo. Sci Immunol (2017) 2:eaal3062. doi: 10.1016/j.physbeh.2017.03.040

85. Li P, Li M, Lindberg MR, Kennett MJ, Xiong N, Wang Y. PAD4 is Essential for Antibacterial Innate Immunity Mediated by Neutrophil Extracellular Traps. J Exp Med (2010) 207:1853-62. doi: 10.1084/jem.20100239

86. Witalison EE, Thompson PR, Hofseth LJ. Protein Arginine Deiminases and Associated Cirtullination: Physiological Functions and Diseases Associated With Dysregulation. Curr Drug Targets (2015) 16:700-10. doi: 10.2174/ 1389450116666150202160954

87. Chang X, Han J, Pang L, Zhao Y, Yang Y, Shen Z. Increased PADI4 Expression in Blood and Tissues of Patients With Malignant Tumors. BMC Cancer (2009) 9:1-11. doi: 10.1186/1471-2407-9-40

88. Wright PW, Bolling LC, Calvert ME, Sarmento OF, Berkeley EV, Shea MC, et al. ePAD, An Oocyte and Early Embryo-Abundant Peptidylarginine Deiminase-Like Protein That Localizes to Egg Cytoplasmic Sheets. Dev Biol (2003) 256:74-89. doi: 10.1016/S0012-1606(02)00126-4

89. Raijmakers R, Zendman AJW, Egberts WV, Vossenaar ER, Raats J, Soedehuijbregts C, et al. Methylation of Arginine Residues Interferes With Citrullination by Peptidylarginine Deiminases In Vitro. J Mol Biol (2007) 1:1118-29. doi: 10.1016/j.jmb.2007.01.054

90. Esposito G, Vitale AM, Leijten FPJ, Strik AM, Koonen-Reemst AMCB, Yurttas P, et al. Peptidylarginine Deiminase (PAD) 6 Is Essential for Oocyte Cytoskeletal Sheet Formation and Female Fertility. Mol Cell Endocrinol (2007) 273:25-31. doi: 10.1016/j.mce.2007.05.005 
91. Tarcsa E, Marekov LN, Mei G, Melino G, Lee SC, Steinert PM. Protein Unfolding by Peptidylarginine Deiminase: Substrate Specificity and Structural Relationships of the Natural Substrates Trichohyalin and Filaggrin. J Biol Chem (1996) 271:30709-16. doi: 10.1074/jbc.271.48.30709

92. Assohou-Luty C, Raijmakers R, Benckhuijsen WE, Stammen-Vogelzangs J, De Ru A, Van Veelen PA, et al. The Human Peptidylarginine Deiminases Type 2 and Type 4 Have Distinct Substrate Specificities. Biochim Biophys Acta - Proteins Proteomics (2014) 1844:829-36. doi: 10.1016/ j.bbapap.2014.02.019

93. Hensen SMM, Pruijn GJM. Methods for the Detection of Peptidylarginine Deiminase (PAD) Activity and Protein Citrullination. Mol Cell Proteomics (2014) 13:388-96. doi: 10.1074/mcp.R113.033746

94. Damgaard D, Senolt L, Nielsen MF, Pruijn GJ, Nielsen CH. Demonstration of Extracellular Peptidylarginine Deiminase (PAD) Activity in Synovial Fluid of Patients With Rheumatoid Arthritis Using a Novel Assay for Citrullination of Fibrinogen. Arthritis Res Ther (2014) 16:498. doi: 10.1186/s13075-014-0498-9

95. Arita K, Hashimoto H, Shimizu T, Nakashima K, Yamada M, Sato M. Structural Basis for Ca2+-Induced Activation of Human PAD4. Nat Struct Mol Biol (2004) 11:777-83. doi: 10.1038/nsmb799

96. Liu GY, Liu YL, Lee CY, Huang YN, Chen HY, Hung HC. Probing the Roles of Calcium-Binding Sites During the Folding of Human Peptidylarginine Deiminase. Sci Rep (2017) 7:1-14. doi: 10.1038/s41598-017-02677-1

97. Wiik AS, van Venrooij WJ, Pruijn GJM. All You Wanted to Know About anti-CCP But Were Afraid to Ask. Autoimmun Rev (2010) 10:90-3. doi: 10.1016/j.autrev.2010.08.009

98. Machold KP, Stamm TA, Nell VPK, Pflugbeil S, Aletaha D, Steiner G, et al. Very Recent Onset Rheumatoid Arthritis: Clinical and Serological Patient Characteristics Associated With Radiographic Progression Over the First Years of Disease. Rheumatology (2007) 46:342-9. doi: 10.1093/ rheumatology/kel237

99. Senshu T, Sato T, Inoue T, Akiyama K, Asaga H. Detection of Citrulline Residues in Deiminated Proteins on Polyvinylidene Difluoride Membrane. Anal Biochem (1992) 203:94-100. doi: 10.1016/0003-2697(92)90047-B

100. Moelants EAV, van Damme J, Proost P. Detection and Quantification of Citrullinated Chemokines. PloS One (2011) 6:6-13. doi: 10.1371/ journal.pone.0028976

101. Bicker KL, Subramanian V, Chumanevich AA, Hofseth LJ, Thompson PR. Seeing Citrulline: Development of a Phenylglyoxal-Based Probe To Visualize Protein Citrullination. J Am Chem Soc (2012) 134:17015-8. doi: 10.1021/ ja308871v

102. Lewallen DM, Bicker KL, Subramanian V, Clancy KW, Slade DJ, Martell J, et al. Chemical Proteomic Platform to Identify Citrullinated Proteins. ACS Chem Biol (2015) 10:2520-8. doi: 10.1021/acschembio.5b00438

103. Nicholas AP, Sambandam T, Echols JD, Barnum SR. Expression of Citrullinated Proteins in Murine Experimental Autoimmune Encephalomyelitis. J Comp Neurol (2005) 486:254-66. doi: 10.1002/ cne.20527

104. Zhou Y, Di Pucchio T, Sims GP, Mittereder N, Mustelin T. Characterization of the Hypercitrullination Reaction in Human Neutrophils and Other Leukocytes. Mediators Inflammation (2015) 2015:236451. doi: 10.1155/ 2015/236451

105. Verheul MK, van Veelen PA, van Delft MAM, de Ru A, Janssen GMC, Rispens T, et al. Pitfalls in the Detection of Citrullination and Carbamylation. Autoimmun Rev (2018) 17:136-41. doi: 10.1016/j.autrev.2017.11.017

106. Clancy KW, Weerapana E, Thompson PR. Detection and Identification of Protein Citrullination in Complex Biological Systems. Curr Opin Chem Biol (2016) 30:1-6. doi: 10.1016/j.cbpa.2015.10.014

107. Wang X, Swensen AC, Zhang T, Piehowski PD, Gaffrey MJ, Monroe ME, et al. Accurate Identification of Deamidation and Citrullination From Global Shotgun Proteomics Data Using a Dual-Search Delta Score Strategy. J Proteome Res (2020) 19:1863-72. doi: 10.1021/acs.jproteome.9b00766

108. Holm A, Rise F, Sessler N, Sollid LM, Undheim K, Fleckenstein B. Specific Modification of Peptide-Bound Citrulline Residues. Anal Biochem (2006) 352:68-76. doi: 10.1016/j.ab.2006.02.007

109. De Ceuleneer M, De Wit V, Van Steendam K, Van Nieuwerburgh F, Tilleman K, Deforce D. Modification of Citrulline Residues With 2,3Butanedione Facilitates Their Detection by Liquid Chromatography/Mass
Spectrometry. Rapid Commun Mass Spectrom (2011) 25:1536-42. doi: $10.1002 / \mathrm{rcm} .5015$

110. Tilvawala R, Nguyen SH, Maurais AJ, Nemmara VV, Nagar M, Salinger AJ, et al. The Rheumatoid Arthritis-Associated Citrullinome. Cell Chem Biol (2018) 25:691-704.e6. doi: 10.1016/j.chembiol.2018.03.002

111. Zullo A, Sommese L, Nicoletti G, Donatelli F, Mancini FP, Napoli C. Epigenetics and Type 1 Diabetes: Mechanisms and Translational Applications. Transl Res (2017) 185:85-93. doi: 10.1016/j.trsl.2017.05.002

112. Rohrbach AS, Slade DJ, Thompson PR, Mowen KA. Activation of PAD4 in NET Formation. Front Immunol (2012) 3:360. doi: 10.3389/fimmu. 2012.00360

113. de Bont CM, Koopman WJH, Boelens WC, Pruijn GJM. StimulusDependent Chromatin Dynamics, Citrullination, Calcium Signalling and ROS Production During NET Formation. Biochim Biophys Acta - Mol Cell Res (2018) 1865:1621-9. doi: 10.1016/j.bbamcr.2018.08.014

114. Damgaard D, Bjørn ME, Jensen PØ, Nielsen CH. Reactive Oxygen Species Inhibit Catalytic Activity of Peptidylarginine Deiminase. J Enzyme Inhib Med Chem (2017) 32:1203-8. doi: 10.1080/14756366.2017.1368505

115. Nagar M, Tilvawala R, Thompson PR. Thioredoxin Modulates Protein Arginine Deiminase 4. Front Immunol (2019) 10:244. doi: 10.3389/ fimmu.2019.00244

116. Damgaard D, Biørn ME, Steffensen MA, Pruijn GJM, Nielsen CH. Reduced Glutathione as a Physiological Co-Activator in the Activation of Peptidylarginine Deiminase. Arthritis Res Ther (2016) 18:1-7. doi: 10.1186/s13075-016-1000-7

117. Eizirik DL, Colli ML, Ortis F. The Role of Inflammation in Insulitis and $\beta$ Cell Loss in Type 1 Diabetes. Nat Rev Endocrinol (2009) 5:219-26. doi: $10.1038 /$ nrendo.2009.21

118. Vig S, Buitinga M, Rondas D, Crèvecoeur I, van Zandvoort M, Waelkens E, et al. Cytokine-Induced Translocation of GRP78 to the Plasma Membrane Triggers a Pro-Apoptotic Feedback Loop in Pancreatic Beta Cells. Cell Death Dis (2019) 10:309. doi: 10.1038/s41419-019-1518-0

119. Eizirik DL, Sammeth M, Bouckenooghe T, Bottu G, Sisino G, Igoillo-Esteve $M$, et al. The Human Pancreatic Islet Transcriptome: Expression of Candidate Genes for Type 1 Diabetes and the Impact of Pro-Inflammatory Cytokines. PloS Gene (2012) 8:e1002552. doi: 10.1371/journal.pgen.1002552

120. Schuit FC, In 't Veld PA, Pipeleers DG. Glucose Stimulates Proinsulin Biosynthesis by a Dose-Dependent Recruitment of Pancreatic Beta Cells. Proc Natl Acad Sci USA (1988) 85:3865-9. doi: 10.1073/pnas.85.11.3865

121. Scheuner D, Kaufman RJ. The Unfolded Protein Response: A Pathway That Links Insulin Demand With $\beta$-Cell Failure and Diabetes. Endocr Rev (2008) 29:317-33. doi: 10.1210/er.2007-0039

122. Hetz C, Papa FR. The Unfolded Protein Response and Cell Fate Control. Mol Cell (2018) 69:169-81. doi: 10.1016/j.molcel.2017.06.017

123. Grootjans J, Kaser A, Kaufman RJ, Blumberg RS. The Unfolded Protein Response in Immunity and Inflammation. Nat Rev Immunol (2016) 16:46984. doi: $10.1038 /$ nri.2016.62

124. Ghosh R, Colon-Negron K, Papa FR. Endoplasmic Reticulum Stress, Degeneration of Pancreatic Islet $\beta$-Cells, and Therapeutic Modulation of the Unfolded Protein Response in Diabetes. Mol Metab (2019) 27:S60-8. doi: 10.1016/j.molmet.2019.06.012

125. Marré ML, James EA, Piganelli JD. $\beta$ Cell ER Stress and the Implications for Immunogenicity in Type 1 Diabetes. Front Cell Dev Biol (2015) 3:67. doi: $10.3389 /$ fcell.2015.00067

126. Marré ML, Piganelli JD. Environmental Factors Contribute to $\beta$ Cell Endoplasmic Reticulum Stress and Neo-Antigen Formation in Type 1 Diabetes. Front Endocrinol (Lausanne) (2017) 8:262. doi: 10.3389/ fendo.2017.00262

127. Marre ML, Mcginty J, Chow I-T, Denicola ME, Beck NW, Kent SC, et al. Modifying Enzymes are Elicited by ER Stress, Generating Epitopes That Are Selectively Recognized by CD4 + T Cells in Patients With Type 1 Diabetes. Diabetes (2018) 67:1356-68. doi: 10.2337/db17-1166

128. Marré ML, Profozich JL, Coneybeer JT, Geng X, Bertera S, Ford MJ, et al. Inherent ER Stress in Pancreatic Islet $\beta$ Cells Causes Self-Recognition by Autoreactive T Cells in Type 1 Diabetes. J Autoimmun (2016) 72:33-46. doi: 10.1016/j.jaut.2016.04.009

129. D’Hertog W, Overbergh L, Lage K, Ferreira GB, Maris M, Gysemans C, et al. Proteomics Analysis of Cytokine-Induced Dysfunction and Death in Insulin- 
Producing INS-1E Cells: New Insights Into the Pathways Involved. Mol Cell Proteomics (2007) 6:2180-99. doi: 10.1074/mcp.M700085-MCP200

130. Christophorou MA, Castelo-Branco G, Halley-Stott RP, Oliveira CS, Loos R, Radzisheuskaya A, et al. Citrullination Regulates Pluripotency and Histone H1 Binding to Chromatin. Nature (2014) 507:104-8. doi: 10.1038/ nature12942

131. Slade DJ, Subramanian V, Thompson PR. Pluripotency: Citrullination Unravels Stem Cells. Nat Chem Biol (2014) 10:327-8. doi: 10.1038/ nchembio. 1504

132. Fuhrmann J, Thompson PR. Protein Arginine Methylation and Citrullination in Epigenetic Regulation. ACS Chem Biol (2016) 11:654-68. doi: 10.1021/acschembio.5b00942

133. Zhang X, Liu X, Zhang M, Li T, Muth A, Thompson PR, et al. Peptidylarginine Deiminase 1-Catalyzed Histone Citrullination Is Essential for Early Embryo Development. Sci Rep (2016) 6:1-11. doi: 10.1038/ srep38727

134. Wang Y, Li M, Stadler S, Correll S, Li P, Wang D, et al. Histone Hypercitrullination Mediates Chromatin Decondensation and Neutrophil Extracellular Trap Formation. J Cell Biol (2009) 184:205-13. doi: 10.1083/ jcb. 200806072

135. Konig MF, Andrade F. A Critical Reappraisal of Neutrophil Extracellular Traps and NETosis Mimics Based on Differential Requirements for Protein Citrullination. Front Immunol (2016) 7:461. doi: 10.3389/fimmu.2016.00461

136. Sharma P, Azebi S, England P, Christensen T, Møller-Larsen A, Petersen T, et al. Citrullination of Histone H3 Interferes With HP1-Mediated Transcriptional Repression. PloS Genet (2012) 8:1-15. doi: 10.1371/ journal.pgen.1002934

137. Guertin MJ, Zhang X, Anguish L, Kim S, Varticovski L, Lis JT, et al. Targeted H3R26 Deimination Specifically Facilitates Estrogen Receptor Binding by Modifying Nucleosome Structure. PloS Genet (2014) 10:1-12. doi: 10.1371/ journal.pgen.1004613

138. Perri AM, Agosti V, Olivo E, Concolino A, Angelis M, Tammè L, et al. Histone Proteomics Reveals Novel Post-Translational Modifications in Breast Cancer. Aging (Albany NY) (2019) 11:11722-55. doi: 10.18632/ aging. 102577

139. Tee WW, Pardo M, Theunissen TW, Yu L, Choudhary JS, Hajkova P, et al. Prmt5 is Essential for Early Mouse Development and Acts in the Cytoplasm to Maintain ES Cell Pluripotency. Genes Dev (2010) 24:2772-7. doi: 10.1101/ gad.606110

140. Deng X, Shao G, Zhang HT, Li C, Zhang D, Cheng L, et al. Protein Arginine Methyltransferase 5 Functions as an Epigenetic Activator of the Androgen Receptor to Promote Prostate Cancer Cell Growth. Oncogene (2017) 36:1223-31. doi: 10.1038/onc.2016.287

141. Cherrington BD, Zhang X, McElwee JL, Morency E, Anguish LJ, Coonrod SA. Potential Role for PAD2 in Gene Regulation in Breast Cancer Cells. PloS One (2012) 7:1-12. doi: 10.1371/journal.pone.0041242

142. Delgado-Rizo V, Martínez-Guzmán MA, Iñiguez-Gutierrez L, GarcíaOrozco A, Alvarado-Navarro A, Fafutis-Morris M. Neutrophil Extracellular Traps and Its Implications in Inflammation: An Overview. Front Immunol (2017) 8:81. doi: 10.3389/fimmu.2017.00081

143. Lewis HD, Liddle J, Coote JE, Atkinson SJ, Barker MD, Bax BD, et al. Inhibition of PAD4 Activity is Sufficient to Disrupt Mouse and Human NET Formation. Nat Chem Biol (2015) 11:181-91. doi: 10.1038/nchembio.1735

144. Khandpur R, Carmona-rivera C, Vivekanandan-giri A, Gizinski A, Yalavarthi S, Knight JS, et al. Nets Are a Source of Citrullinated Autoantigens and Stimulate Inflammatory Responses in Rheumatoid Arthritis. Rheum Arthritis (2013) 5:1-10. doi: 10.1126/scitranslmed.3005580

145. Pratesi F, Dioni I, Tommasi C, Alcaro MC, Paolini I, Barbetti F, et al. Antibodies From Patients With Rheumatoid Arthritis Target Citrullinated Histone 4 Contained in Neutrophils Extracellular Traps. Ann Rheum Dis (2014) 73:1414-22. doi: 10.1136/annrheumdis-2012-202765

146. Diana J, Simoni Y, Furio L, Beaudoin L, Agerberth B, Barrat F, et al. Crosstalk Between Neutrophils, B-1a Cells and Plasmacytoid Dendritic Cells Initiates Autoimmune Diabetes. Nat Med (2013) 19:65-73. doi: 10.1038/nm.3042

147. Qin J, Fu S, Speake C, Greenbaum CJ, Odegard JM. Netosis-Associated Serum Biomarkers Are Reduced in Type 1 Diabetes in Association With Neutrophil Count. Clin Exp Immunol (2016) 184:318-22. doi: 10.1111/ cei. 12783
148. Wang Y, Xiao Y, Zhong L, Ye D, Zhang J, Tu Y, et al. Increased Neutrophil Elastase and Proteinase 3 and Augmented NETosis Are Closely Associated With $\beta$-Cell Autoimmunity in Patients With Type 1 Diabetes. Diabetes (2014) 63:4239-48. doi: 10.2337/db14-0480

149. Harsunen MH, Puff R, D’Orlando O, Giannopoulou E, Lachmann L, Beyerlein A, et al. Reduced Blood Leukocyte and Neutrophil Numbers in the Pathogenesis of Type 1 Diabetes. Horm Metab Res (2013) 45:467-70. doi: $10.1055 / \mathrm{s}-0032-1331226$

150. Valle A, Giamporcaro GM, Scavini M, Stabilini A, Grogan P, Bianconi E, et al. Reduction of Circulating Neutrophils Precedes and Accompanies Type 1 Diabetes. Diabetes (2013) 62:2072-7. doi: 10.2337/db12-1345

151. Vecchio F, Buono N, Stabilini A, Nigi L, Dufort MJ, Geyer S, et al. Abnormal Neutrophil Signature in the Blood and Pancreas of Presymptomatic and Symptomatic Type 1 Diabetes. JCI Insight (2018) 3:1-17. doi: 10.1172/ JCI.INSIGHT.122146

152. Ling Wong S, Demers M, Martinod K, Gallant M, Wang Y, Goldfine ABB, et al. Diabetes Primes Neutrophils to Undergo NETosis, Which Impairs Wound Healing. Nat Med (2015) 21:815-9. doi: 10.1038/nm.3887

153. El Shikh MEM, El Sayed R, Nerviani A, Goldmann K, John CR, Hands R, et al. Extracellular Traps and PAD4 Released by Macrophages Induce Citrullination and Auto-Antibody Production in Autoimmune Arthritis. J Autoimmun (2019) 105:102297. doi: 10.1016/j.jaut.2019.06.008

154. Sharma P, Lioutas A, Fernandez-Fuentes N, Quilez J, Carbonell-Caballero J, Wright RHG, et al. Arginine Citrullination At the C-Terminal Domain Controls Rna Polymerase II Transcription. Mol Cell (2019) 73:84-96.e7. doi: 10.1016/j.molcel.2018.10.016

155. Proost P, Loos T, Mortier A, Schutyser E, Gouwy M, Noppen S, et al. Citrullination of CXCL8 by Peptidylarginine Deiminase Alters Receptor Usage, Prevents Proteolysis, and Dampens Tissue Inflammation. J Exp Med (2008) 205:2085-97. doi: 10.1084/jem.20080305

156. Loos T, Mortier A, Gouwy M, Ronsse I, Put W, Lenaerts JP, et al. Citrullination of CXCL10 and CXCL11 by Peptidylarginine Deiminase: A Naturally Occurring Posttranslational Modification of Chemokines and New Dimension of Immunoregulation. Blood (2008) 112:2648-56. doi: 10.1182/ blood-2008-04-149039

157. Struyf S, Noppen S, Loos T, Mortier A, Gouwy M, Verbeke H, et al. Citrullination of CXCL12 Differentially Reduces CXCR4 and CXCR7 Binding With Loss of Inflammatory and Anti-HIV-1 Activity Via CXCR4. J Immunol (2009) 182:666-74. doi: 10.4049/jimmunol.182.1.666

158. Moelants EAV, Mortier A, Grauwen K, Ronsse I, Van Damme J, Proost P. Citrullination of TNF- $\alpha$ by Peptidylarginine Deiminases Reduces its Capacity to Stimulate the Production of Inflammatory Chemokines. Cytokine (2013) 61:161-7. doi: 10.1016/j.cyto.2012.09.011

159. Kondo K, Ohigashi I, Takahama Y. Thymus Machinery for T-cell Selection. Int Immunol (2019) 31:119-25. doi: 10.1093/intimm/dxy081

160. Derbinski J, Schulte A, Kyewski B, Klein L. Promiscuous Gene Expression in Medullary Thymic Epithelial Cells Mirrors the Peripheral Self. J Immunol (2001) 2:1032-9. doi: 10.1038/ni723

161. Delong T, Baker RL, Reisdorph N, Reisdorph R, Powell RL, Armstrong M, et al. Islet Amyloid Polypeptide is a Target Antigen for Diabetogenic CD4 + T Cells. Diabetes (2011) 60:2325-30. doi: 10.2337/db11-0288

162. Raposo B, Merky P, Lundqvist C, Yamada H, Urbonaviciute V, Niaudet C, et al. T Cells Specific for Post-Translational Modifications Escape Intrathymic Tolerance Induction. Nat Commun (2018) 9:353. doi: 10.1038/s41467-017-02763-y

163. Engelmann R, Biemelt A, Cordshagen A, Johl A, Kuthning D, Müller-Hilke B. The Prerequisites for Central Tolerance Induction Against Citrullinated Proteins in the Mouse. PloS One (2016) 11:1-11. doi: 10.1371/ journal.pone. 0158773

164. Rodriguez-Calvo T, Johnson JD, Overbergh L, Dunne JL. Neoepitopes in Type 1 Diabetes: Etiological Insights, Biomarkers and Therapeutic Targets. Front Immunol (2021) 12:667989. doi: 10.3389/fimmu.2021.667989

165. Crèvecoeur I, Gudmundsdottir V, Vig S, Marques Câmara Sodré F, D’Hertog W, Fierro AC, et al. Early Differences in Islets From Prediabetic NOD Mice: Combined Microarray and Proteomic Analysis. Diabetologia (2017) 60:47589. doi: $10.1007 /$ s00125-016-4191-1

166. Hayashi H, Morioka M, Ichimiya S, Yamato K, Hinode D, Nagata A. Nakamura R. Participation of an Arginyl Residue of Insulin Chain B in the Inhibition of 
Hemagglutination by Porphyromonas Gingivalis. Oral Microbiol Immunol (1993) 8:386-9. doi: 10.1111/j.1399-302X.1993.tb00616.x

167. Nguyen H, James EA. Immune Recognition of Citrullinated Epitopes. Immunology (2016) 149:131-8. doi: 10.1111/imm.12640

168. Mamula MJ, Gee RJ, Elliott JI, Sette A, Southwood S, Jones PJ, et al. Isoaspartyl Post-Translational Modification Triggers Autoimmune Responses to Self-Proteins. J Biol Chem (1999) 274:22321-7. doi: 10.1074/ jbc.274.32.22321

169. Yang M-LL, Doyle HA, Clarke SG, Herold KC, Mamula MJ. Oxidative Modifications in Tissue Pathology and Autoimmune Disease. Antioxid Redox Signal (2018) 29:1415-31. doi: 10.1089/ars.2017.7382

170. Lehmann PV, Forsthuber T, Miller A, Sercarz EE. Spreading of T-cell Autoimmunity to Cryptic Determinants of an Autoantigen. Nature (1992) 358:155-7. doi: 10.1038/358155a0

171. Doyle HA, Aswad DW, Mamula MJ. Autoimmunity to Isomerized Histone H2B in Systemic Lupus Erythematosus. Autoimmunity (2013) 46:6-13. doi: 10.3109/08916934.2012.710859

172. Kidd BA, Ho PP, Sharpe O, Zhao X, Tomooka BH, Kanter JL, et al. Epitope Spreading to Citrullinated Antigens in Mouse Models of Autoimmune Arthritis and Demyelination. Arthritis Res Ther (2008) 10:1-12. doi: $10.1186 /$ ar2523

173. Arbuckle MR, McClain MT, Rubertone MV, Scofield RH, Dennis GJ, James JA, et al. Development of Autoantibodies Before the Clinical Onset of Systemic Lupus Erythematosus. N Engl J Med (2003) 349:1526-33. doi: 10.1056/nejmoa021933

174. Gergely P, Grossman C, Niland B, Puskas F, Neupane H, Allam F, et al. Mitochondrial Hyperpolarization and ATP Depletion in Patients With Systemic Lupus Erythematosus. Arthritis Rheum (2002) 46:175-90. doi: 10.1002/1529-0131(200201)46:1<175::AID-ART10015>3.0.CO;2-H

175. Gergely P, Niland B, Gonchoroff N, Pullmann R, Phillips PE, Perl A. Persistent Mitochondrial Hyperpolarization, Increased Reactive Oxygen Intermediate Production, and Cytoplasmic Alkalinization Characterize Altered IL-10 Signaling in Patients With Systemic Lupus Erythematosus. J Immunol (2002) 169:1092-101. doi: 10.4049/jimmunol.169.2.1092

176. Becart S, Whittington KB, Prislovsky A, Rao NL, Rosloniec F E. The Role of Posttranslational Modifications in Generating Neo-Epitopes That Bind to Rheumatoid Arthritis-Associated HLA-DR Alleles and Promote Autoimmune T Cell Responses. PloS One (2021) 16:1-22. doi: 10.1371/ journal.pone.0245541

177. Travers TS, Harlow L, Rosas IO, Gochuico BR, Mikuls TR, Bhattacharya SK, et al. Extensive Citrullination Promotes Immunogenicity of HSP90 Through Protein Unfolding and Exposure of Cryptic Epitopes. J Immunol (2016) 197:1926-36. doi: 10.4049/jimmunol.1600162

178. Manoury B, Mazzeo D, Fugger L, Viner N, Ponsford M, Streeter H, et al. Destructive Processing by Asparagine Endopeptidase Limits Presentation of a Dominant T Cell Epitope in MBP. Nat Immunol (2002) 3:169-74. doi: $10.1038 / n i 754$

179. Gahring LC, Carlson NG, Meyer EL, Rogers SW. Cutting Edge: Granzyme B Proteolysis of a Neuronal Glutamate Receptor Generates an Autoantigen and Is Modulated by Glycosylation. J Immunol (2001) 166:1433-8. doi: 10.4049/ jimmunol.166.3.1433

180. Johnson BA, Aswad DW. Fragmentation of Isoaspartyl Peptides and Proteins by Carboxypeptidase Y: Release of Isoaspartyl Dipeptides as a Result of Internal and External Cleavage. Biochemistry (1990) 29:4373-80. doi: 10.1021/bi00470a017

181. Moss CX, Matthews SP, Lamont DJ, Watts C. Asparagine Deamidation Perturbs Antigen Presentation on Class II Major Histocompatibility Complex Molecules. J Biol Chem (2005) 280:18498-503. doi: 10.1074/ jbc.M501241200

182. Mamula MJ. The Inability to Process a Self-Peptide Allows Autoreactive T Cells to Escape Tolerance. J Exp Med (1993) 177:567-71. doi: 10.1084/ jem.177.2.567

183. Mamula MJ. Lupus Autoimmunity; From Peptides to Particles. Immunol Rev (1995) 144:301-14. doi: 10.1111/j.1600-065X.1995.tb00074.x

184. Mamula MJ. Epitope Spreading: The Role of Self Peptides and Autoantigen Processing by B Lymphocytes. Immunol Rev (1998) 164:231-3. doi: 10.1111/ j.1600-065X.1998.tb01223.x
185. Casciola-Rosen LA, Miller DK, Anhalt GJ, Rosen A. Specific Cleavage of the $70-\mathrm{kDa}$ Protein Component of the U1 Small Nuclear Ribonucleoprotein is a Characteristic Biochemical Feature of Apoptotic Cell Death. J Biol Chem (1994) 269:30757-60. doi: 10.1016/s0021-9258(18)47343-7

186. Ireland JM, Unanue ER. Autophagy in Antigen-Presenting Cells Results in Presentation of Citrullinated Peptides to CD4 T Cells. J Exp Med (2011) 208:2625-32. doi: $10.1084 /$ jem.20110640

187. Harvey BP, Gee RJ, Haberman AM, Shlomchik MJ, Mamula MJ. Antigen Presentation and Transfer Between B Cells and Macrophages. Eur J Immunol (2007) 37:1739-51. doi: 10.1002/eji.200636452

188. Harvey BP, Quan TE, Rudenga BJ, Roman RM, Craft J, Mamula MJ. Editing Antigen Presentation: Antigen Transfer Between Human B Lymphocytes and Macrophages Mediated by Class A Scavenger Receptors. J Immunol (2008) 181:4043-51. doi: 10.4049/jimmunol.181.6.4043

189. Raycroft MT, Harvey BP, Bruck MJ, Mamula MJ. Inhibition of Antigen Trafficking Through Scavenger Receptor A. J Biol Chem (2012) 287:5310-6. doi: 10.1074/jbc.M111.316356

190. Hill JA, Southwood S, Sette A, Jevnikar AM, Bell DA, Cairns E. The Conversion of Arginine to Citrulline Allows for a High-Affinity Peptide Interaction With the Rheumatoid Arthritis-Associated HLA-DRB1*0401 Mhc Class II Molecule. J Immunol (2003) 171:538-41. doi: 10.4049/ jimmunol.171.2.538

191. Haan ECD, Wagenaar-Hilbers JPA, Liskamp RMJ, Moret EE, Wauben MHM. Limited Plasticity in T Cell Recognition of Modified T Cell Receptor Contact Residues in MHC Class II Bound Peptides. Mol Immunol (2005) 42:355-64. doi: 10.1016/j.molimm.2004.07.044

192. Slade DJ, Fang P, Dreyton CJ, Zhang Y, Fuhrmann J, Rempel D, et al. Protein Arginine Deiminase 2 Binds Calcium in an Ordered Fashion: Implications for Inhibitor Design. ACS Chem Biol (2015) 10:1043-53. doi: 10.1021/ cb500933j

193. Stone EM, Schaller TH, Bianchi H, Person MD, Fast W. Inactivation of Two Diverse Enzymes in the Amidinotransferase Superfamily by 2Chloroacetamidine: Dimethylargininase and Peptidylarginine Deiminase. Biochemistry (2005) 44:13744-52. doi: 10.1021/bi051341y

194. Muth A, Subramanian V, Beaumont E, Nagar M, Kerry P, Mcewan P, et al. Development of a Selective Inhibitor of Protein Arginine Deiminase 2. J Med Chem (2017) 60:3198-211. doi: 10.1021/acs.jmedchem.7b00274

195. Mondal S, Thompson PR. Protein Arginine Deiminases (Pads): Biochemistry and Chemical Biology of Protein Citrullination. Acc Chem Res (2019) 52:818-32. doi: 10.1021/acs.accounts.9b00024

196. Johnson DS, Weerapana E, Cravatt BF. Strategies for Discovering and Derisking Covalent, Irreversible Enzyme Inhibitors. Future Med Chem (2010) 2:949-64. doi: 10.4155/fmc.10.21

197. Nemmara VV, Thompson PR. Development of Activity-Based Proteomic Probes for Protein Citrullination. Curr Top Microbiol Immunol (2019) 420:233-51. doi: 10.1007/82

198. Lewis HD, Nacht M. IPAD or PADi - "Tablets" With Therapeutic Disease Potential? Curr Opin Chem Biol (2016) 33:169-78. doi: 10.1016/ j.cbpa.2016.06.020

199. Bruggeman Y, Sodré FMC, Buitinga M, Mathieu C, Kracht MJL. Expert Opinion on Therapeutic Targets Targeting Citrullination in Autoimmunity: Insights Learned From Preclinical Mouse Models Models. Expert Opin Ther Targets (2021), 1-13. doi: 10.1080/14728222.2021.1918104

200. Sodré FMC, Bissenova S, Bruggeman Y, Tilvawala R, Cook DP, Berthault C, et al. Peptidylarginine Deiminase Inhibition Prevents Diabetes Development in NOD Mice. Diabetes (2021) 70:516-28. doi: 10.2337/db20-0421

201. Kawalkowska J, Quirke AM, Ghari F, Davis S, Subramanian V, Thompson PR, et al. Abrogation of Collagen-Induced Arthritis by a Peptidyl Arginine Deiminase Inhibitor Is Associated With Modulation of T Cell-Mediated Immune Responses. Sci Rep (2016) 6:1-12. doi: 10.1038/srep26430

202. Chumanevich AA, Causey CP, Knuckley BA, Jones JE, Poudyal D, Chumanevich AP, et al. Suppression of Colitis in Mice by Cl-Amidine: A Novel Peptidylarginine Deiminase Inhibitor. Am J Physiol - Gastrointest Liver Physiol (2011) 300:929-38. doi: 10.1152/ajpgi.00435.2010

203. Willis VC, Gizinski AM, Banda NK, Causey CP, Knuckley B, Cordova KN, et al. N- $\alpha$-Benzoyl-N5-(2-Chloro-1-Iminoethyl)-L-Ornithine Amide, A Protein Arginine Deiminase Inhibitor, Reduces the Severity of Murine 
Collagen-Induced Arthritis. J Immunol (2011) 186:4396-404. doi: 10.4049/ jimmunol.1001620

204. Knight JS, Zhao W, Luo W, Subramanian V, Dell AAO, Yalavarthi S, et al. Peptidylarginine Deiminase Inhibition Is Immunomodulatory and Vasculoprotective in Murine Lupus. J Clin Invest (2013) 123:2981-93. doi: 10.1172/JCI67390.ex

205. Knight JS, Subramanian V, O’Dell AA, Yalavarthi S, Zhao W, Smith CK, et al. Peptidylarginine Deiminase Inhibition Disrupts NET Formation and Protects Against Kidney, Skin and Vascular Disease in Lupus-Prone MRL/ Lpr Mice. Ann Rheum Dis (2015) 74:2199-206. doi: 10.1136/annrheumdis-2014-205365

206. Kawaguchi H, Matsumoto I, Osada A, Kurata I, Ebe H, Tanaka Y, et al. Peptidyl Arginine Deiminase Inhibition Suppresses Arthritis Via Decreased Protein Citrullination in Joints and Serum With the Downregulation of Interleukin-6. Mod Rheumatol (2019) 29:964-9. doi: 10.1080/ 14397595.2018 .1532545

207. Ghari F, Quirke AM, Munro S, Kawalkowska J, Picaud S, McGouran J, et al. Citrullination-Acetylation Interplay Guides E2F-1 Activity During the Inflammatory Response. Sci Adv (2016) 2:e1501257. doi: 10.1126/ sciadv. 1501257

208. Papadaki G, Kambas K, Choulaki C, Vlachou K, Drakos E, Bertsias G, et al. Neutrophil Extracellular Traps Exacerbate Th1-Mediated Autoimmune Responses in Rheumatoid Arthritis by Promoting DC Maturation. Eur J Immunol (2016) 46:2542-54. doi: 10.1002/eji.201646542

209. Luo Y, Arita K, Bhatia M, Knuckley B, Lee YH, Stallcup MR, et al. Inhibitors and Inactivators of Protein Arginine Deiminase 4: Functional and Structural Characterization. Biochemistry (2006) 45:11727-36. doi: 10.1021/bi061180d
210. Makrygiannakis D, Af Klint E, Lundberg IE, Löfberg R, Ulfgren AK, Klareskog L, et al. Citrullination Is an Inflammation-Dependent Process. Ann Rheum Dis (2006) 65:1219-22. doi: 10.1136/ard.2005.049403

211. Bicker KL, Anguish L, Chumanevich AA, Cameron MD, Cui X, Witalison E, et al. D-Amino Acid-Based Protein Arginine Deiminase Inhibitors: Synthesis, Pharmacokinetics, and in Cellulo Efficacy. ACS Med Chem Lett (2012) 3:1081-5. doi: 10.1021/ml300288d

212. Jones JE, Slack JL, Fang P, Zhang X, Subramanian V, Causey CP, et al. Synthesis and Screening of a Haloacetamidine Containing Library to Identify PAD4 Selective Inhibitors. ACS Chem Biol (2012) 7:160-5. doi: 10.1021/ cb200258q

213. Willis VC, Banda NK, Cordova KN, Chandra PE, Robinson WH, Cooper DC, et al. Protein Arginine Deiminase 4 Inhibition Is Sufficient for the Amelioration of Collagen-Induced Arthritis. Clin Exp Immunol (2017) 188:263-74. doi: $10.1111 /$ cei.12932

Conflict of Interest: The authors declare that the research was conducted in the absence of any commercial or financial relationships that could be construed as a potential conflict of interest.

Copyright (c) 2021 Yang, Sodré, Mamula and Overbergh. This is an open-access article distributed under the terms of the Creative Commons Attribution License (CC BY). The use, distribution or reproduction in other forums is permitted, provided the original author(s) and the copyright owner(s) are credited and that the original publication in this journal is cited, in accordance with accepted academic practice. No use, distribution or reproduction is permitted which does not comply with these terms. 